\title{
USING DESIGN-BASED CHANGE ORDERS AS A LESSONS LEARNED METRIC IN UNIVERSITY \\ DORMITORY CONSTRUCTION
}

by

MATTHEW LEE COLE STONE

\begin{abstract}
A THESIS
Submitted in partial fulfillment of the requirements for the degree of Master of Science in the Department of Civil Engineering in the Graduate School of

The University of Alabama
\end{abstract}

TUSCALOOSA, ALABAMA 
Copyright Matthew Lee Cole Stone 2009 ALL RIGHTS RESERVED 


\begin{abstract}
The enrollment at The University of Alabama has increased substantially in recent years and the University is expanding to meet the growing demands. The expansion includes four dormitory complexes built within the past five years. Change orders considerably influenced the final cost of the first and second dormitory projects and the University initiated the current study to follow-up on a global change order study that previously examined new construction on campus. The current study is part of a lessons learned initiative to improve the cost-effectiveness of University construction projects. New dormitory construction projects were the main focus of this study and the change data from these facilities was analyzed based on the reasons for the change and what Construction Specifications Institute (CSI) Division the change represented. While it was determined that the largest source of change orders on dormitory projects were owner initiated, these changes have not been targeted for reduction since they are at the discretion of the University and can be beneficial to the project. To gauge the performance of the change management program currently in place at the University, the direct impact on the total project cost due to changes resulting from design errors were analyzed for all four dormitory projects. The author hopes that the recommendations in this study will aid universities and colleges by providing a means to gather, track, and analyze changes that occur during the construction of dormitory projects and show how the lessons learned from the change orders during these projects can potentially reduce costs on future projects.
\end{abstract}




\section{ACKNOWLEDGMENTS}

First and foremost, I would like to offer my gratitude to my adviser, Dr. Philip Johnson, for his understanding and imparting his knowledge of the subject during this research. I am also indebted to Tim Leopard for sharing his expertise and patience during my time at Construction Administration. Great appreciation is given to my committee members, Dr. Edward Back and Dr. David Grau, for their participation and contribution to this research. It is also my pleasure to thank Dr. Lynda Gilbert for providing me with the opportunity and resources necessary to finish this work. Personal gratitude is extended to my parents and Tamara Smelley for their encouragement and full support throughout the totality of this endeavor. 


\section{CONTENTS}

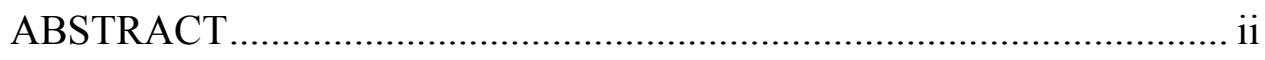

ACKNOWLEDGMENTS ................................................................ iii

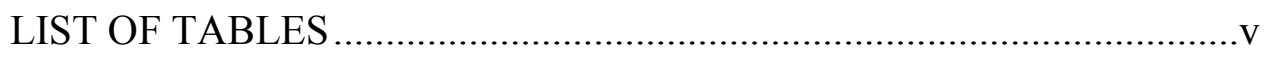

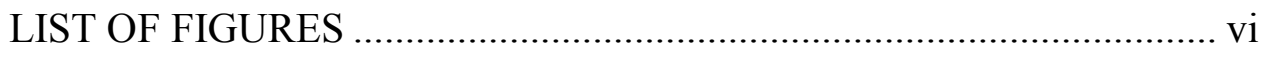

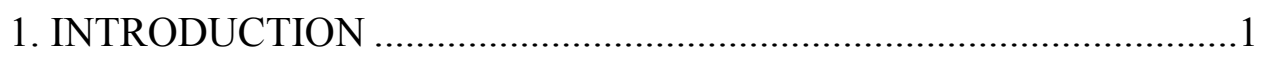

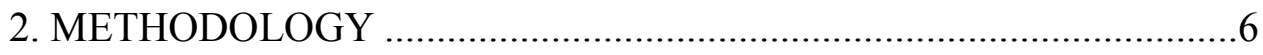

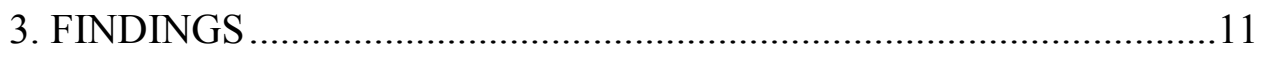

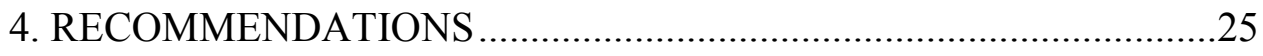

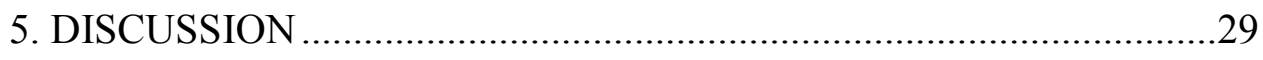

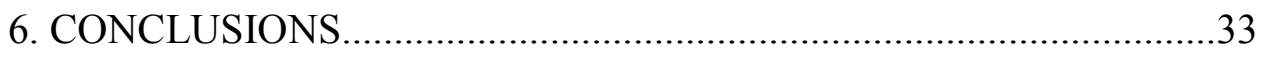

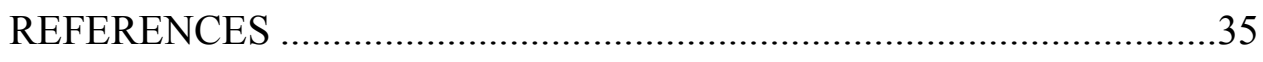

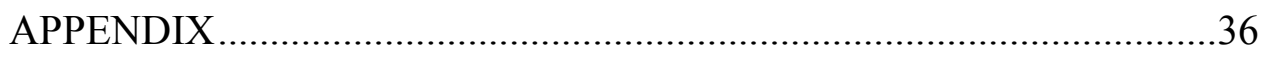




\section{LIST OF TABLES}

1. Table 1: CSI Divisions Per Residential Community ...........................18

2. Table 2: CSI Divisions Per Residential Community Costs ..................22

3. Table 3: Dormitory Design Change Order Totals Percentage of

Project Costs ............................................................................. 23

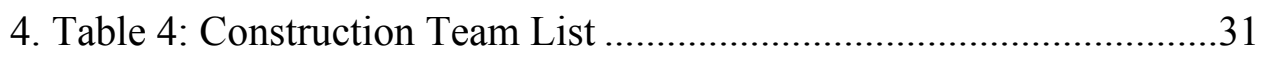




\section{LIST OF FIGURES}

1. Figure 1: Number of Change Orders Originating from Design Problems

2. Figure 2: Project Cost Percentage of Change Orders from Design

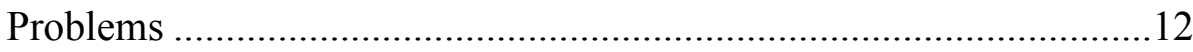

3. Figure 3: Analysis of Dormitory Change Order Reasons ................... 14

4. Figure 4: Project Cost Percentage of Dormitory Change Order Reasons

5. Figure 5: Number of Dormitory Change Order Occurrences by CSI

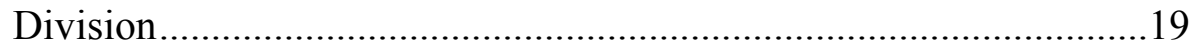

6. Figure 6: Project Cost Percentage of Dormitory Change Order by CSI

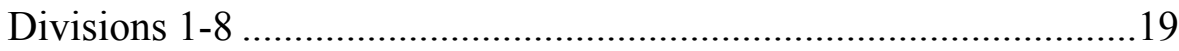

7. Figure 7: Project Cost Percentage of Dormitory Change Order by CSI

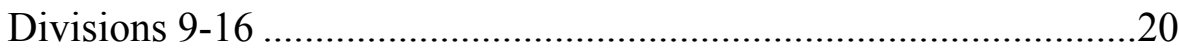




\section{CHAPTER 1}

\section{INTRODUCTION}

The University of Alabama, as part of a planned expansion, has experienced a rapid and steady growth in enrollment in recent years. The enrollment for the Fall 2004 semester was 20,969 while the Fall 2009 semester enrollment reached 28,807 students, averaging a growth of over 1,500 students per year in a five-year span. This increase has placed a significant strain on the University's ability to facilitate the needs of incoming students, faculty, and staff by providing up-to-date housing complexes, academic buildings, and campus infrastructure. An extensive building plan has been launched including construction of new facilities and the renovation of existing structures, but there were significant issues with budget overruns and delayed completion dates on several projects. The University hypothesized that a considerable number of change orders, especially changes due to design errors, are a controllable source of reduced control of a project's cost and schedule.

A change order is a "formal directive change to the construction contract that typically includes a change in work scope, an adjusted contract price, and any changes to the time to perform the work" (O’Brien 1998). Change orders that are common during projects can be divided into three main categories: the scope of the project changes because of a change in owner requirements, the work must be performed differently because of conditions unforeseen when the contract was agreed to, and the design must be adjusted because of omissions in the contract documents or design features that cannot be built as specified (Gould 2003). Owner initiated 
changes are items that can be added or deleted from the project scope to satisfy any changes to the requirements of the project. Another owner initiated change is value engineering; this type of change is under the direction of the owner but involves savings recommendations from the prime contractor due to their experience of materials and construction methods (Clough 2005). Owner initiated changes are the most straightforward to process since there is no dispute over the reasoning for the change order (Günhan 2007). Unforeseen changes can include undiscovered soil types not documented during the geotechnical site analysis or, for instance, the discovery of an old disposal area during earthmoving operations. A change order resulting from interference is another example of an unforeseen change and typically involves the hindrance of a contractor due to the defective or incomplete work of another contractor or the activities of the owner. This type of change cannot be predicted by the owner, designers, or contractor (CII 1991). Change orders resulting from improper design are described as the failure of the designer to adequately specify all project components to an acceptable level so that the contractor can proceed with construction (Günhan 2007). City and state officials may require design changes due to code violations once they have inspected the building.

The direct impact a change order has on a construction project affects both the project budget and schedule. The effects these changes have can be rather insignificant or very costly to the project and can include productivity degradation, schedule delays, material that is wasted in rework, and the time and cost associated with tearing out already completed work (CII 1990). While these factors will typically have the most impact on the project cost and schedule, there are also indirect effects that can degrade the performance of the project. Examples of indirect impacts can include items such as increased overhead costs associated with reviewing and processing the change order, either extending the project time or crashing the schedule to meet a 
hard deadline, and changes to the subcontracts (CII 1990). The number of change order items issued by the owner can also be a contributing factor in the impact to the cost and schedule performance of a project. A study under the guidance of the Construction Industry Institute Project Change Management Research Team determined that the more change there is in a project, the more negative impact it has on labor productivity (Ibbs 1995). Research conducted to study the effects change orders had on the labor efficiency of mechanical contractors found that there was a significant statistical relationship between the number of changes and the probability a project would be impacted by these changes (Hanna 1999).

Prior to this study, research had been performed to address issues the University had concerning the numerous change orders and the exceptional accompanying cost that was being added to large capital projects such as dormitories, parking garages, research and classroom buildings, and other campus buildings like fraternity and sorority housing. A review of the data and the conclusions that were drawn from that research gave some insight into the nature of the change order environment that occurs during the construction of campus facilities and provided ideas for possible mitigation strategies that could be employed to negate, or at the very least lessen, the detrimental effects these changes were having on campus building projects. Since the previous project showed that over half of the change orders during campus construction were the result of design problems, a system was developed that was intended to reduce the number of design-based changes based on the lessons learned from where, when, and why changes occurred. This system included a checklist for use during the review of design documents. The use of checklists is nothing new in the construction industry. For instance, weighted checklists are an integral part during the front-end planning phase of a project. The Project Definition Rating Index (PDRI) developed by the Construction Industry Institute (CII) is a 
checklist that is used by project managers to rate the level of scope definition for a given project. This tool was initially developed for industrial projects but a PDRI has also been developed for building construction projects. The building project PDRI can be used from the project assessment/feasibility phase up until the development of detailed design documents. The checklist consists of 64 elements that allow an individual to evaluate the status of a building project during the front-end planning phase in regard to the project's scope definition (Cho 2001). Good scores on this checklist have been shown to indicate projects that are likely to finish on or ahead of schedule, below budget, and with fewer occurrences of project changes. A design review checklist comprised of change items that appeared during previous like projects is intended to offer similar benefits.

The purpose of this study was to measure the direct impact of design based changes on project cost and to determine whether the checklist developed in the previous study was effective in reducing design-based change orders similar to those found in the previous dormitory projects. This research study would also examine how lessons learned from the dormitory construction program can be implemented into the University's change management system to minimize the effects caused by excessive and costly design-based changes during future projects at the University. This study focused on dormitory construction projects due to the fact that two new building complexes were built since the recommendations on reducing change orders were provided, and these new facilities would provide a direct before and after comparison. While previous research focused on when the change order occurred in the project timeline and at what cost, the focal point of this study was to determine what construction specialty area, such as structural, landscaping, or mechanical changes, was the main cause of the change orders and how to incorporate the findings into the lessons learned program. 
The data from the two campus dormitories analyzed in the previous study, Riverside Residential Community and Lakeside Residential Community, was reexamined and compared to the change data from Ridgecrest North Residential Community and Ridgecrest South Residential Community, the two new dormitory complexes that were constructed after the initial research was conducted. Riverside Residential Community is a three building complex that houses a total of 304 dwelling units distributed across the four floors of the buildings. Built in 2005, the gross square footage of this community is 377,882 square feet. The Lakeside complex, constructed in 2006 , is comprised of two buildings accommodating 176 units with a total gross square footage of 225,621 square feet. Both of these dormitory complexes feature similar exterior and interior architectural styles and amenities. Ridgecrest North is a dormitory complex that was finished in 2007 and contains two buildings housing a total of 168 total dwelling units and provides up to 245,680 square feet of usage. Ridgecrest South Residential Community was the final dormitory analyzed; the Ridgecrest South complex facility consists of five floors built upon a three deck parking garage to minimize land usage. This complex houses 254 residential units occupying 345,425 square feet atop the 425,019 square foot parking deck and was finished before the 2009 fall semester. The same principal architectural firm designed all of the aforementioned dormitory complexes and contract delivery was by the traditional design-bid-build method. 


\section{CHAPTER 2}

\section{METHODOLOGY}

To measure how effectively the reduction program is performing in decreasing the number and cost of change orders seen during construction of sizeable university projects, metrics that can be easily categorized and interpreted would be needed to effectively sort and analyze data as well as provide informative feedback. According to the CII, the five criteria that must be met for a metric to be effective include:

1. Measurability,

2. Significance to the organization and project team,

3. Ability to be influenced in some predictable way by management action,

4. Repeatability, and

5. Timeliness (CII 1994).

Examples of metrics commonly used in change order management include the cost of the change; the type, origin, and impact of the change order; the time at which the change occurs during the project life-cycle; and the engineering function or craft trade involved (CII 1994). Since some of these metrics were already implemented in the previous study, new metrics were needed so that the individual change order line items could be further examined so that modifications could be made to the existing change order reduction program already in use.

One of the main objectives of the metrics within this study was to identify the basis for the change order. The reason for the change order was entered into a spreadsheet based on the most common types of change orders that occur during construction projects. The four 
categories used in this study were owner initiated changes, design error changes, unforeseen conditions, and value engineering. The value engineering changes were separated from the owner initiated changes in this study because all of the value engineering changes were negative or zero dollar amounts and these changes would not subtract from the owner initiated changes that resulted in a positive dollar amount. The reason for the change was determined from the change order justification form. This includes a description that lists who initiated the change, the justification of the need for the change, and the type of change. These three descriptions would provide the necessary detail to determine in which reason category the change belonged. Value engineering changes were designated with a "VE" next to the change line item. By grouping the change order items together by the reason for the change, the University could observe the causes of the change order throughout the building program and determine who or what was ultimately responsible for the change that was necessary to complete the project. This type of information would be very beneficial to compare the values experienced during the dormitory construction program to industry benchmarks and to develop a change management lessons learned process.

Another parameter necessary to track where change orders come from is the construction specialty or trade that was affected by the change. It was determined that the best method to evaluate this parameter was to assign each change order line item a number from the Construction Specifications Institute (CSI) MasterFormat Divisions based on the construction specialty affected by the change. Similar to the reason for the change order parameter, the line entries that are analyzed by CSI Divisions would also enable the University to track who was responsible for the change. The 1995 version of MasterFormat was chosen over the 2004 edition since the 1995 version is exclusively used by the University's Construction Administration 
department as well as the local designers and contractors who worked on the dormitory projects. To enhance the detail of the traditional CSI MasterFormat Divisions, the sixteen divisions were broken down into subdivisions; these subdivisions showed what specific area of construction was the cause for the majority of change orders within dormitory projects and provided some insight into why they may be a recurring problem if the same change was needed for more than one dormitory project. This analysis would also allow for a more detailed comparison to items found on checklist that may be discovered in the design documents based on reviewer's comments. A list of the CSI Divisions and the sub-divisions used in this study can be seen in Appendix 1.

The first step in this research study was to gather, organize, and analyze the dormitory construction change order data the University had available for Riverside, Lakeside, Ridgecrest North, and Ridgecrest South. The basic format of the spreadsheet that was developed in the first research project was reused to allow for easy data sorting and organization and to provide more consistency throughout the data set so that further improvements could be made to the conclusions gathered in the former study. The spreadsheet used in the previous study divided the change order items by the project, the principal architect/engineer, change order work item (the specific dilemma that developed on the construction site and the required actions that were necessary to address the problem), and the cost of the specific change item. Other parameters included the project start and finish dates, the change order initiation date, the duration of the project, the number of days after the project was started until the day of change order initiation, the percentage of time into the project when the change occurred, the percentage of cost of the change based on the total project cost, and the reason for the change order.

For this study, a few of the spreadsheet headings, including the project name, the principal architect/engineer, the change order line item, and the cost of the line item were 
retained and used again, but the columns containing the project start and finish dates, the change order initiation date, and the percentages of time and cost were omitted since the knowledge originating from this information, such as when the majority of changes occurred and how they affected University projects, had already been reported and was not the main focus of this study. However, to provide a more comprehensive analysis of the change items, headings that included points like the changes to the completion date (measured in days), the reason for the change order, and the CSI Division of the change were incorporated into the spreadsheet. In one instance three Divisions of work were represented in one change order line item. To ensure that the number of occurrences was accounted for in the correct Division, the cost of work in each Division illustrated in the change line item was divided by the total change order line item cost and that percentage was added to the number of occurrences within their respective CSI Division. After entering all of the data into the spreadsheet, the change order items were then grouped based on the CSI Division impacted by the change order item and by the reason for the change. All of the occurrences were then analyzed based on the reasons for the change order and the CSI Division that encompassed the change for a given dormitory. Both of the metrics were also combined and examined to determine the most problematic areas for all dormitory construction projects on campus.

During the initial change order study, a checklist was developed based on frequently occurring change items that were found in the change orders for dormitory, research, and parking garage construction. The main purpose of this checklist was to aid the in-house design professionals in the contract document review process. By utilizing the checklist, the reviewers would be able to examine the plans and specifications at the $10,30,60,90$, and 100 percent completion design phase to find common design errors and omissions and other problematic 
areas that were observed in previous dormitory construction projects. These checklists were also to be used to determine if the materials, location and type of equipment, etc. comply with University standards so that problems that could result in costly change orders are properly mitigated at a lower impact to the overall project budget and schedule. In-house designers at the University used this checklist during the planning and design phases of Ridgecrest North and Ridgecrest South to review the design documents for major campus projects. To determine if any items on the checklist were found in the plans and specifications for the new dormitory projects, the design review comments posted by the architect and engineers on staff at the University were cross-referenced with the checklist items. The checklist was also used by the author during the review of the Ridgecrest South project to see if any items on the checklist were found in the plans and specifications. 


\section{CHAPTER 3}

\section{FINDINGS}

The previous study on change orders that occurred during the construction of University facilities showed that the total number of change order items for the Riverside and Lakeside projects were 86 and 43 , respectively. The total cost associated with change orders for the Riverside community was $\$ 1,875,900$ while the final change order cost for Lakeside totaled $\$ 693,298$. This constituted a $50 \%$ decrease of total change order items (43 items) from the construction of Riverside to Lakeside with a reduction of $63 \%$, or $\$ 1,182,603$, in the total cost of changes between the two projects. The change orders during the Riverside project constituted $6.88 \%$ of the final cost of construction while the changes during the Lakeside project amounted to $2.65 \%$ of the final cost.

The new dormitory complexes Ridgecrest North and Ridgecrest South were two of the first large capital projects commissioned by the University that utilized the checklist to catch deficiencies within the design documents during the design review stage of the project time-line. The changes made during the construction of the new dormitories would need to be measured against the change order data from the previous dormitory projects in order to determine the performance these checklists had on reducing the amount of change orders. After the construction of Ridgecrest North and South was completed, the number of change order line items and the total cost was tabulated for each complex. Overall, the number of change items during the construction of the Ridgecrest North project totaled 61 change order items at an 
overall cost of $\$ 814,625$, approximately $2.43 \%$ of the final cost, while the Ridgecrest South dormitory project experienced 50 change order items at an overall cost of $\$ 320,539$. The changes during the Ridgecrest South project represented $0.68 \%$ of the final project cost.

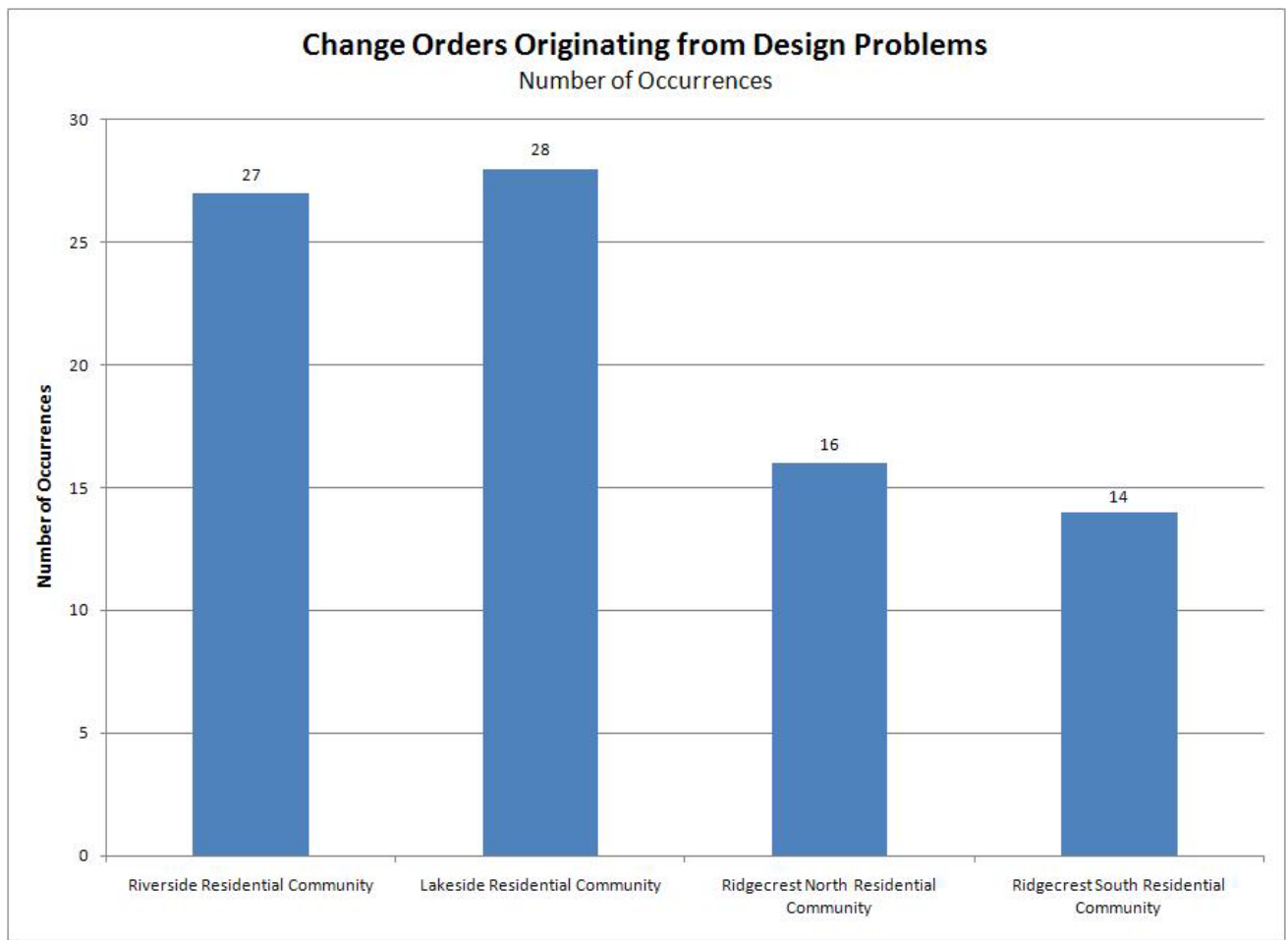

Fig. 1. Number of Change Orders Originating from Design Problems

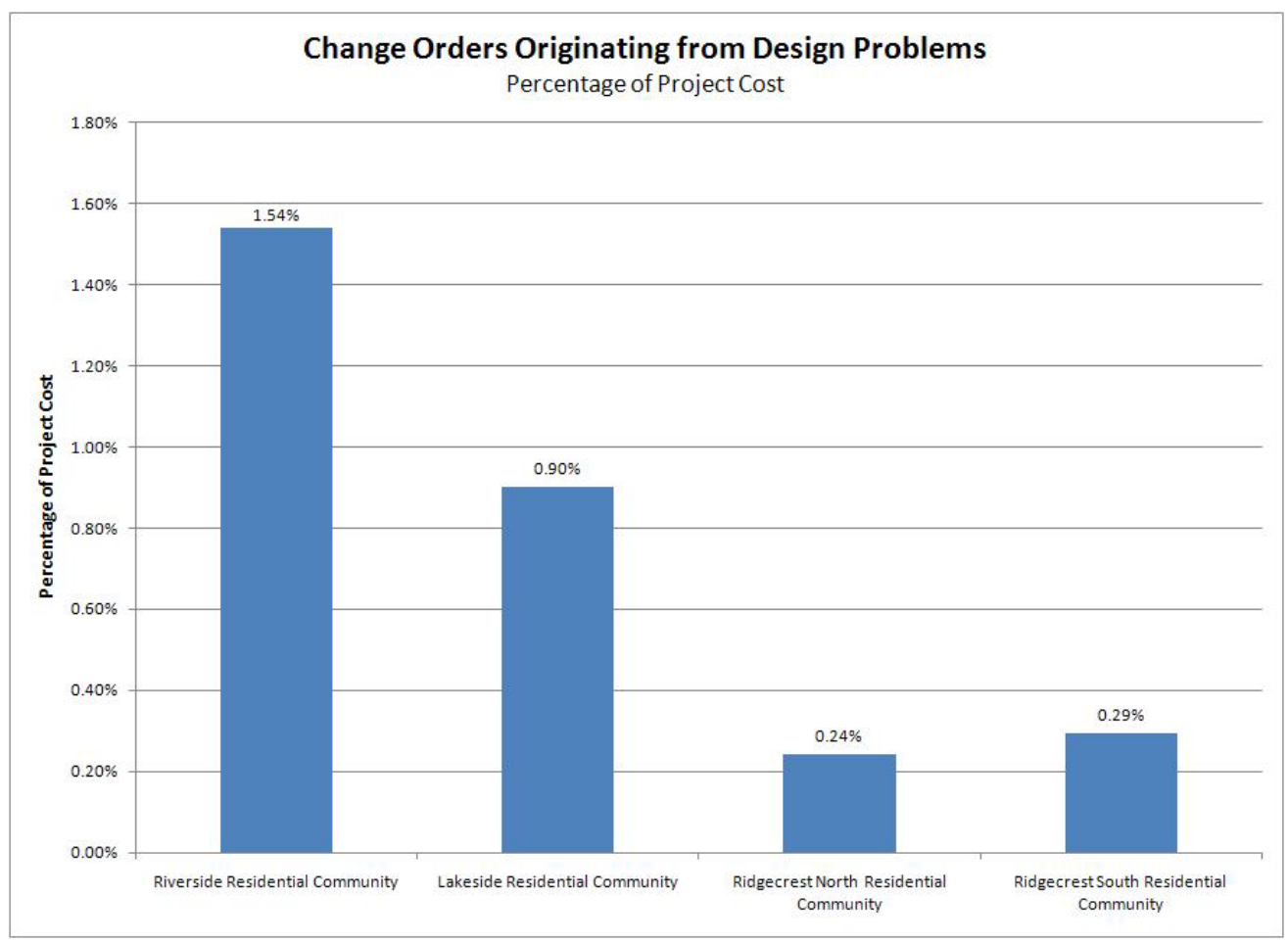

Fig. 2. Project Cost Percentage of Change Orders from Design Problems 
As seen in Figures 1 and 2, by the end of the dormitory construction program change orders resulting from design related problems had been reduced to 16 occurrences for Ridgecrest North and 14 changes for Ridgecrest South when compared to the 27 occurrences for Riverside and 28 change orders for Lakeside. During the construction of the first three facilities of the program, the percentage of total project cost due to design changes also decreased from $1.54 \%$ for Riverside to $0.24 \%$ for Ridgecrest North while the percentage for Ridgecrest South increased slightly to $0.29 \%$.

The two main contributors to changes identified by the previous study of campus construction projects were owner directed changes and deficiencies within the design documents. For example, owner initiated changes during the construction of Riverside accounted for nearly $40 \%$ of the number of change order items and increased the contract amount by approximately $8.5 \%$ of the total contract amount. The hefty cost of changes experienced during the Riverside project was a cause for concern and warranted a close examination of the change order management system currently in place at the University. Even though the overall cost of change orders during the following dormitory project, the Lakeside community, was significantly lower and did not cause an extreme increase in the project cost, owner directed changes still accounted for approximately $60 \%$ of the total change order cost during construction.

For all of the projects combined, the reasons for change that generated the most change order initiations were owner requests, design errors, and value engineering items with a total of 107, 85, and 34 items, respectively. Owner initiated changes represented a large part of the dormitory total change order cost. These changes totaled $\$ 4,041,402$, or $3.01 \%$ of the total project costs. Deficient design documents also directly impacted the cost of the projects by adding $0.65 \%$ to the final costs. Value engineering, as expected, resulted in savings close to 
$\$ 1,500,000$ for all projects. A graph depicting the total number of occurrences per reason for the change order and the total cost for each reason can be seen in Figures 3 and 4, respectively.

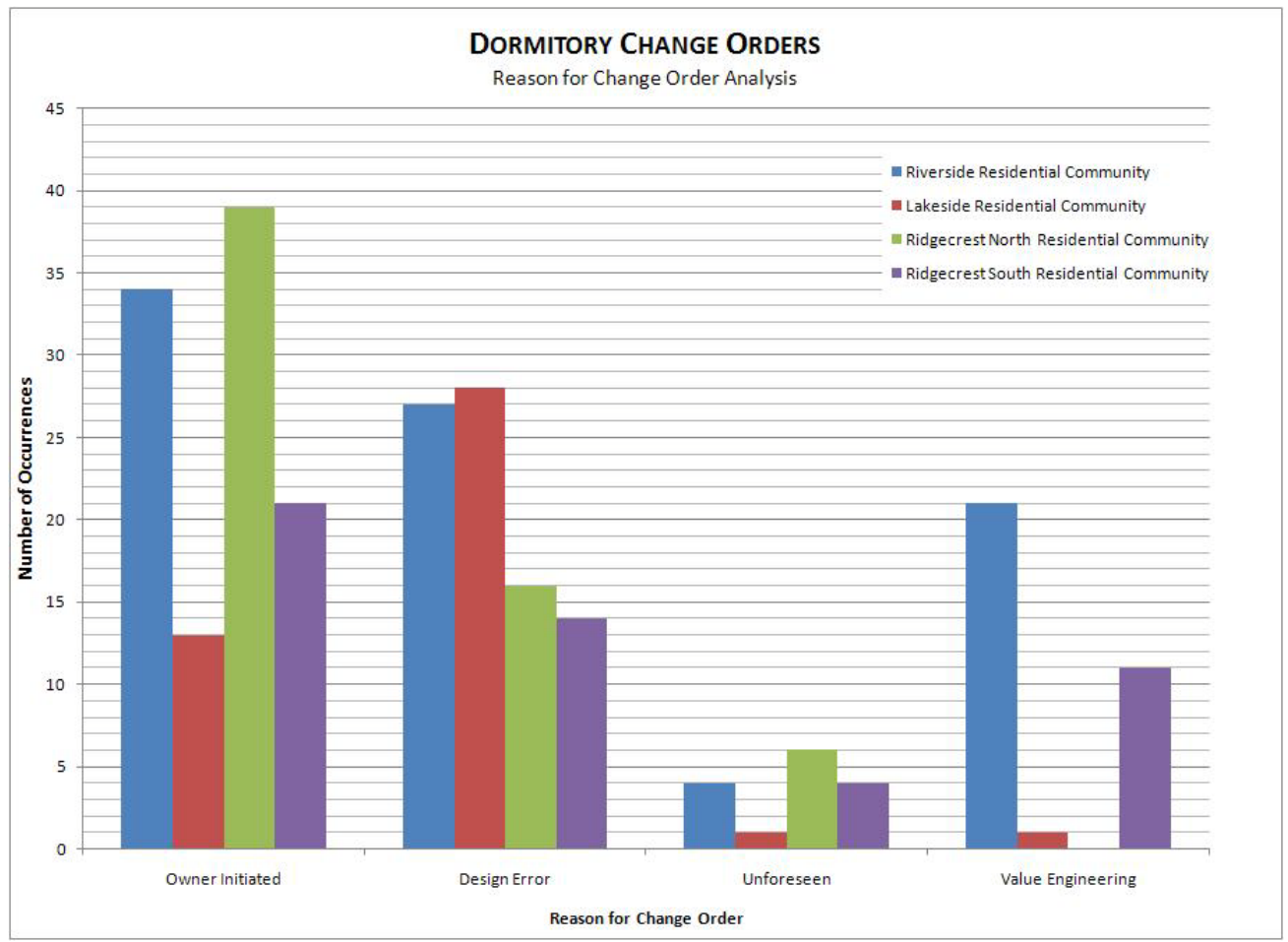

Fig. 3. Analysis of Dormitory Change Order Reasons

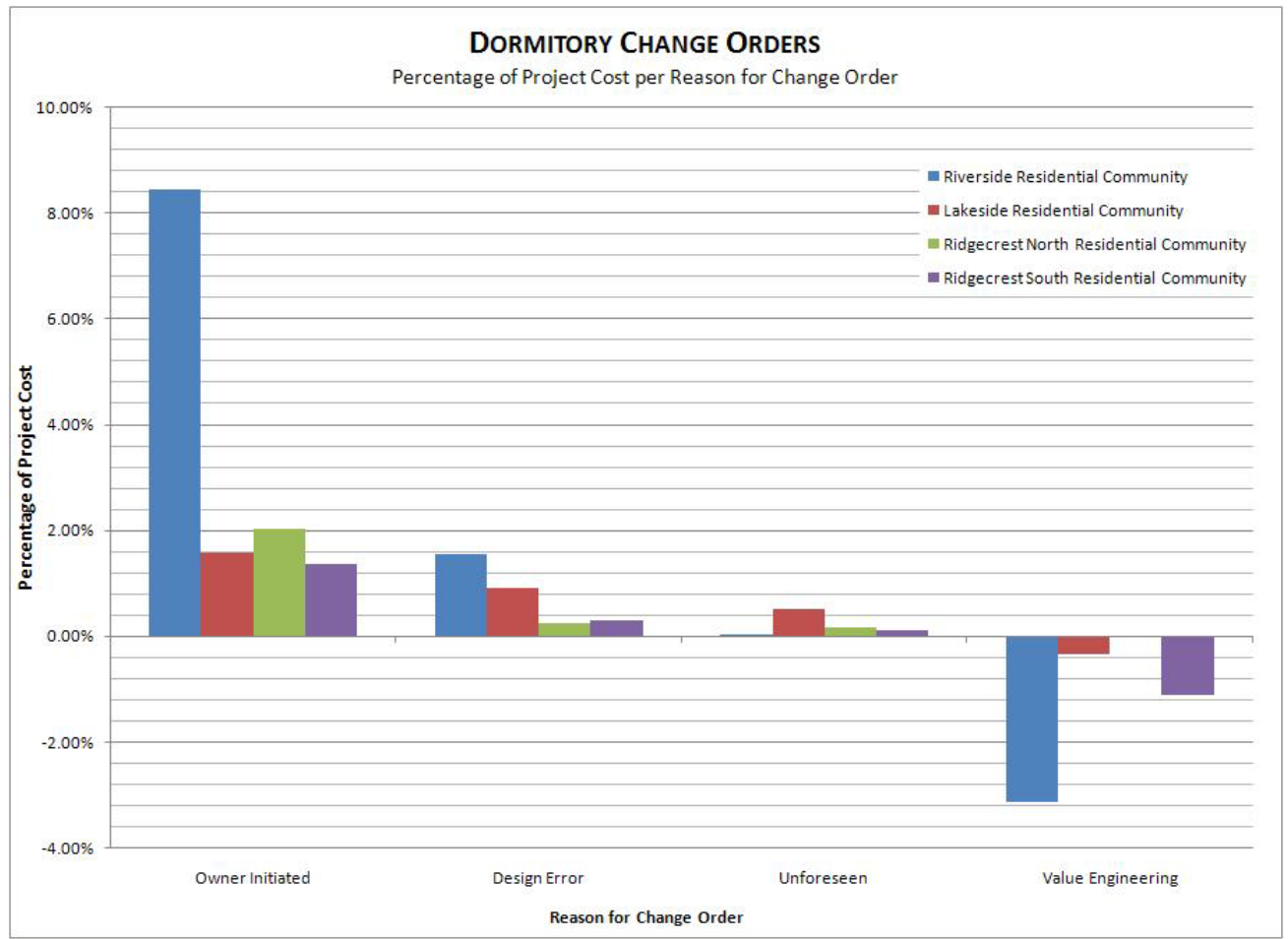

Fig. 4. Project Cost Percentage of Dormitory Change Order Reasons 
Although owner initiated changes accounted for the majority of change orders during the dormitory construction program, this does not necessarily mean that they should be targeted for reduction. While any change to the project scope during the planning or design phase of a project will undoubtedly be a more cost efficient alternative, changes made by a formal change order after construction has begun may be the only option the University has available. As a public institution, several scenarios could unfold that would cause the University to initiate an addition to the project or request an alteration to the project scope. One such instance would be if extra funding became available unexpectedly where the University would be forced to use the money or lose it. Another example would be adding to the scope after key risk points, such as after the foundation has been constructed with minimal disruption, have been passed without the University having to use much of the project contingency for changes. The main target for reduction still remains design-based change orders.

As a whole, the CSI Division that generated the most change orders for all four dormitory projects was Division 2 - Site Construction. This section produced the highest number of occurrences for all projects, producing 73.2 of the 240 change order items, and it also greatly impacted the final cost of the projects by increasing the contracted amounts by over 2 million dollars. However, both the number of occurrences of site construction changes and the costs associated with them progressively improved throughout the dormitory construction program. The sub-division within Division 2 that produced the most change orders was 2.7 - Bases, Ballasts, Pavements, and Appurtenances, representing almost 25\% of the total Division 2 change order cost. Construction in Division 9 - Finishes and Division 16 - Electrical were also responsible for costly change orders during the dormitory program. Work in Division 9 had ten 
change items totaling $\$ 889,247$, or $0.66 \%$ of the total cost of the projects, while construction under Division 16 had 31.5 occurrences at a cost of $\$ 745,057$, or $0.56 \%$.

Between the construction of Riverside and Lakeside, there was a substantial decrease in the number of change order items related to Divisions $2,4,8,9,13$, and 15 . These sections demonstrated a considerable reduction, ranging from 50 to 100 percent, in the total number of occurrences within their respective divisions. While this reduction in the number of items was significant, it did not translate into a drop in the total cost of the change order items for Divisions 8 and 15. These areas increased in cost by $\$ 16,544(0.9 \%)$ and $\$ 255,222(0.95 \%)$, respectively. The other CSI Divisions for Lakeside either had the same number of changes as Riverside or saw an increase in the number of items. These divisions also saw an increase in the total cost of the change order items as compared to the changes associated with their respective divisions within the Riverside project. Compared to the Riverside dormitory, Ridgecrest North experienced a drop in the total number of change order items and the total cost of change orders associated with the project. From the CSI Division analysis, Divisions 2, 4, 9, 10, 12, 13, and 16 had a reduction in the total divisional costs. The largest reduction in cost between Riverside and Ridgecrest North was Division 2; the final total for this Division within Ridgecrest North was $\$ 492,939$ ( $1.47 \%$ of total project cost) versus the $\$ 905,097$ (3.32\%) total for Riverside site construction change orders. The number of costly site construction changes was also substantially reduced during the construction of Ridgecrest South when compared to the previous three projects. Only a $0.08 \%$ increase in the project cost was due to Division 2 changes during the construction of this facility. Another area of significant improvement was Division 9; Riverside had five Division 9 change order items that totaled $\$ 731,845$, approximately $2.69 \%$ of the project cost, while Ridgecrest North had four change items with an increase in cost of $0.45 \%$ to the total 
project cost. Ridgecrest South had zero Division 9 change orders. The change order costs by CSI Division for each dormitory can be seen in Table 1 and Figures 5, 6, and 7. 


\begin{tabular}{|c|c|c|c|c|c|c|c|}
\hline \multicolumn{8}{|c|}{ Riverside Residential Community } \\
\hline \multicolumn{2}{|r|}{ CSI Divisions } & \multirow{2}{*}{$\begin{array}{c}\begin{array}{c}\text { Number of CO } \\
\text { Items }\end{array} \\
6.3\end{array}$} & $\begin{array}{c}\text { Percentage of } \\
\text { Total Occurrences }\end{array}$ & \multicolumn{2}{|r|}{ Cost } & $\begin{array}{l}\text { Percentage of } \\
\text { Total co Cost }\end{array}$ & $\begin{array}{c}\text { Percentage of } \\
\text { Project Cost }\end{array}$ \\
\hline Division 1 & General Requirements & & $7.3 \%$ & $\$$ & $(130,766)$ & $-7.0 \%$ & $-0.48 \%$ \\
\hline Division $\mathbf{2}$ & Site Construction & 29.2 & $34.0 \%$ & $\$$ & 905,098 & $48.2 \%$ & $3.32 \%$ \\
\hline Division 3 & Concrete & 0 & $0.0 \%$ & $\$$ & - & $0.0 \%$ & $0.00 \%$ \\
\hline Division 4 & Masonry & 4 & $4.7 \%$ & $\$$ & 5,746 & $0.3 \%$ & $0.02 \%$ \\
\hline Division 5 & Metals & 2 & $2.3 \%$ & $\$$ & 6,572 & $0.4 \%$ & $0.02 \%$ \\
\hline Division 6 & Wood and Plastics & 0 & $0.0 \%$ & $\$$ & - & $0.0 \%$ & $0.00 \%$ \\
\hline Division 7 & Thermal and Moisture Protection & 2 & $2.3 \%$ & $\$$ & $(7,309)$ & $-0.4 \%$ & $-0.03 \%$ \\
\hline Division 8 & Doors and Windows & 5 & $5.8 \%$ & $\$$ & $(15,610)$ & $-0.8 \%$ & $-0.06 \%$ \\
\hline Division 9 & Finishes & 5 & $5.8 \%$ & $\$$ & 731,845 & $39.0 \%$ & $2.69 \%$ \\
\hline Division 10 & Specialties & 2 & $2.3 \%$ & $\$$ & 82,046 & $4.4 \%$ & $0.30 \%$ \\
\hline Division 11 & Equipment & 2 & $2.3 \%$ & $\$$ & $(103,811)$ & $-5.5 \%$ & $-0.38 \%$ \\
\hline Division 12 & Furnishings & 0 & $0.0 \%$ & $\$$ & - & $0.0 \%$ & $0.00 \%$ \\
\hline Division 13 & Special Construction & 7 & $8.1 \%$ & $\$$ & 200,527 & $10.7 \%$ & $0.74 \%$ \\
\hline Division 14 & Conveying Systems & 1 & $1.2 \%$ & $\$$ & $(110,000)$ & $-5.9 \%$ & $-0.40 \%$ \\
\hline Division 15 & Mechanical & 15 & $17.4 \%$ & $\$$ & $(175,923)$ & $-9.4 \%$ & $-0.65 \%$ \\
\hline \multirow[t]{2}{*}{ Division 16} & Electrical & 5.5 & $6.4 \%$ & $\$$ & 487,485 & $26.0 \%$ & $1.79 \%$ \\
\hline & & 86 & & $\$$ & $1,875,900$ & & \\
\hline
\end{tabular}

\begin{tabular}{|c|c|c|c|c|c|c|c|}
\hline \multicolumn{2}{|r|}{ CSI Divisions } & \multirow{2}{*}{$\begin{array}{c}\begin{array}{c}\text { Number of CO } \\
\text { Items }\end{array} \\
6\end{array}$} & \multirow{2}{*}{$\begin{array}{c}\begin{array}{c}\text { Percentage of } \\
\text { Total Occurrences }\end{array} \\
14.0 \%\end{array}$} & \multicolumn{2}{|r|}{ Cost } & \multirow{2}{*}{$\begin{array}{c}\begin{array}{c}\text { Percentage of } \\
\text { Total co Cost }\end{array} \\
-2.4 \%\end{array}$} & \multirow{2}{*}{$\begin{array}{c}\begin{array}{c}\text { Percentage of } \\
\text { Project Cost }\end{array} \\
-0.06 \%\end{array}$} \\
\hline Division 1 & General Requirements & & & $\$$ & $\begin{array}{l}(16,877) \\
\end{array}$ & & \\
\hline Division 2 & Site Construction & 13 & $30.2 \%$ & $\$$ & 593,412 & $85.6 \%$ & $2.27 \%$ \\
\hline Division 3 & Concrete & 0 & $0.0 \%$ & $\$$ & - & $0.0 \%$ & $0.00 \%$ \\
\hline Division 4 & Masonry & 0 & $0.0 \%$ & $\$$ & & $0.0 \%$ & $0.00 \%$ \\
\hline Division 5 & Metals & 3 & $7.0 \%$ & $\$$ & 17,465 & $2.5 \%$ & $0.07 \%$ \\
\hline Division 6 & Wood and Plastics & 0 & $0.0 \%$ & $\$$ & - & $0.0 \%$ & $0.00 \%$ \\
\hline Division 7 & Thermal and Moisture Protection & 1 & $2.3 \%$ & $\$$ & 1,200 & $0.2 \%$ & $0.00 \%$ \\
\hline Division 8 & Doors and Windows & 1 & $2.3 \%$ & $\$$ & 934 & $0.1 \%$ & $0.00 \%$ \\
\hline Division 9 & Finishes & 1 & $2.3 \%$ & $\$$ & 5,813 & $0.8 \%$ & $0.02 \%$ \\
\hline Division 10 & Specialties & 3 & $7.0 \%$ & $\$$ & $(12,591)$ & $-1.8 \%$ & $-0.05 \%$ \\
\hline Division 11 & Equipment & 0 & $0.0 \%$ & $\$$ & - & $0.0 \%$ & $0.00 \%$ \\
\hline Division 12 & Furnishings & 2 & $4.7 \%$ & $\$$ & 548 & $0.1 \%$ & $0.00 \%$ \\
\hline Division 13 & Special Construction & 0 & $0.0 \%$ & $\$$ & - & $0.0 \%$ & $0.00 \%$ \\
\hline Division 14 & Conveying Systems & 0 & $0.0 \%$ & s & - & $0.0 \%$ & $0.00 \%$ \\
\hline Division 15 & Mechanical & 8 & $18.6 \%$ & $\$$ & 79,299 & $11.4 \%$ & $0.30 \%$ \\
\hline \multirow[t]{2}{*}{ Division 16} & Electrical & 5 & $11.6 \%$ & $\$$ & 24,095 & $3.5 \%$ & $0.09 \%$ \\
\hline & & 43 & & $\$$ & 693,298 & & \\
\hline
\end{tabular}

\begin{tabular}{|c|c|c|c|c|c|c|c|}
\hline \multicolumn{8}{|c|}{ Ridgecrest North Residential Community } \\
\hline \multicolumn{2}{|r|}{ CSI Divisions } & $\begin{array}{c}\text { Number of } \mathrm{CO} \\
\text { Items }\end{array}$ & $\begin{array}{c}\text { Percentage of } \\
\text { Total Occurrences }\end{array}$ & \multicolumn{2}{|r|}{ Cost } & $\begin{array}{l}\text { Percentage of } \\
\text { Total co Cost } \\
\end{array}$ & $\begin{array}{l}\text { Percentage of } \\
\text { Project Cost } \\
\end{array}$ \\
\hline Division 1 & General Requirements & 3 & $4.9 \%$ & $\overline{\$} \$$ & $(38,610.00)$ & $-4.8 \%$ & $-0.11 \%$ \\
\hline Division 2 & Site Construction & 29 & $47.5 \%$ & $\$$ & $492,939.15$ & $60.9 \%$ & $1.47 \%$ \\
\hline Division 3 & Concrete & 1 & $1.6 \%$ & $\$$ & $4,044.00$ & $0.5 \%$ & $0.01 \%$ \\
\hline Division 4 & Masonry & 0 & $0.0 \%$ & $\$$ & - & $0.0 \%$ & $0.00 \%$ \\
\hline Division 5 & Metals & 0 & $0.0 \%$ & $\$$ & - & $0.0 \%$ & $0.00 \%$ \\
\hline Division 6 & Wood and Plastics & 0 & $0.0 \%$ & $\$$ & - & $0.0 \%$ & $0.00 \%$ \\
\hline Division 7 & Thermal and Moisture Protection & 0 & $0.0 \%$ & $\$$ & - & $0.0 \%$ & $0.00 \%$ \\
\hline Division 8 & Doors and Windows & 1 & $1.6 \%$ & $\$$ & $16,000.00$ & $2.0 \%$ & $0.05 \%$ \\
\hline Division 9 & Finishes & 4 & $6.6 \%$ & $\$$ & $151,589.00$ & $18.7 \%$ & $0.45 \%$ \\
\hline Division 10 & Specialties & 2 & $3.3 \%$ & $\$$ & $31,032.00$ & $3.8 \%$ & $0.09 \%$ \\
\hline Division 11 & Equipment & 0 & $0.0 \%$ & $\$$ & - & $0.0 \%$ & $0.00 \%$ \\
\hline Division 12 & Furnishings & 1 & $1.6 \%$ & s & $(17,700.00)$ & $-2.2 \%$ & $-0.05 \%$ \\
\hline Division 13 & Special Construction & 0 & $0.0 \%$ & $\$$ & - & $0.0 \%$ & $0.00 \%$ \\
\hline Division 14 & Conveying Systems & 1 & $1.6 \%$ & $\$$ & $93,405.00$ & $11.5 \%$ & $0.28 \%$ \\
\hline Division 15 & Mechanical & 15 & $24.6 \%$ & $\$$ & $69,089.00$ & $8.5 \%$ & $0.21 \%$ \\
\hline \multirow[t]{4}{*}{ Division 16} & Electrical & 4 & $6.6 \%$ & $\$$ & $7,671.00$ & $0.9 \%$ & $0.02 \%$ \\
\hline & & 61 & & $\$$ & 809,459 & & \\
\hline & & \multicolumn{4}{|c|}{ Ridgecrest South Residential Community } & & \\
\hline & CSI Divisions & $\begin{array}{c}\text { Number of } \mathrm{CO} \\
\text { Items }\end{array}$ & $\begin{array}{c}\text { Percentage of } \\
\text { Total Occurrences }\end{array}$ & & Cost & $\begin{array}{l}\text { Percentage of } \\
\text { Total co cost }\end{array}$ & $\begin{array}{l}\text { Percentage of } \\
\text { Project Cost }\end{array}$ \\
\hline Division 1 & General Requirements & $\overline{3}$ & $6.0 \%$ & $\overline{\$ \$}$ & 83,548 & $26.1 \%$ & $0.18 \%$ \\
\hline Division 2 & Site Construction & 2 & $4.0 \%$ & $\$$ & 39,747 & $12.4 \%$ & $0.08 \%$ \\
\hline Division 3 & Concrete & 4 & $8.0 \%$ & s & 14,377 & $4.5 \%$ & $0.03 \%$ \\
\hline Division 4 & Masonry & 2 & $4.0 \%$ & $\$$ & $(60,311)$ & $-18.8 \%$ & $-0.13 \%$ \\
\hline Division 5 & Metals & 1 & $2.0 \%$ & $\$$ & $(140,000)$ & $-43.7 \%$ & $-0.30 \%$ \\
\hline Division 6 & Wood and Plastics & 0 & $0.0 \%$ & $\$$ & - & $0.0 \%$ & $0.00 \%$ \\
\hline Division 7 & Thermal and Moisture Protection & 7 & $14.0 \%$ & $\$$ & 21,064 & $6.6 \%$ & $0.04 \%$ \\
\hline Division 8 & Doors and Windows & 4 & $8.0 \%$ & $\$$ & 200,736 & $62.6 \%$ & $0.43 \%$ \\
\hline Division 9 & Finishes & 0 & $0.0 \%$ & s & - & $0.0 \%$ & $0.00 \%$ \\
\hline Division 10 & Specialties & 1 & $2.0 \%$ & $\$$ & 65,816 & $20.5 \%$ & $0.14 \%$ \\
\hline Division 11 & Equipment & 1 & $2.0 \%$ & $\$$ & $(180,000)$ & $-56.2 \%$ & $-0.38 \%$ \\
\hline Division 12 & Furnishings & 0 & $0.0 \%$ & s & & $0.0 \%$ & $0.00 \%$ \\
\hline Division 13 & Special Construction & 4 & $8.0 \%$ & $\$$ & 8,366 & $2.6 \%$ & $0.02 \%$ \\
\hline Division 14 & Conveying Systems & 1 & $2.0 \%$ & $\$$ & $(23,000)$ & $-7.2 \%$ & $-0.05 \%$ \\
\hline Division 15 & Mechanical & 3 & $6.0 \%$ & s & 64,390 & $20.1 \%$ & $0.14 \%$ \\
\hline Division 16 & Electrical & 17 & $34.0 \%$ & $\$$ & 225,806 & $70.4 \%$ & $0.48 \%$ \\
\hline
\end{tabular}

Table 1. CSI Divisions Per Residential Community 


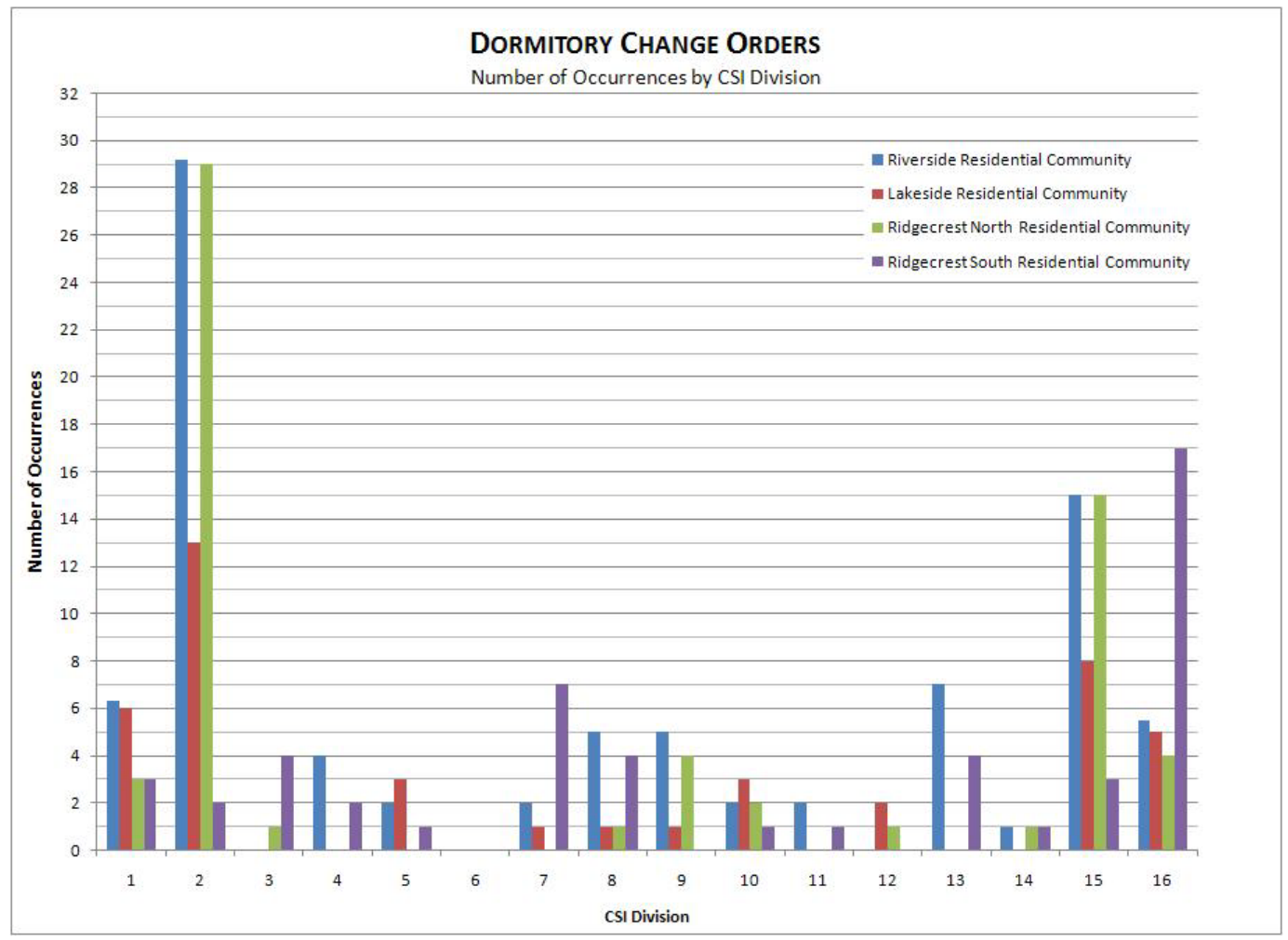

Fig. 5. Number of Dormitory Change Order Occurrences by CSI Division

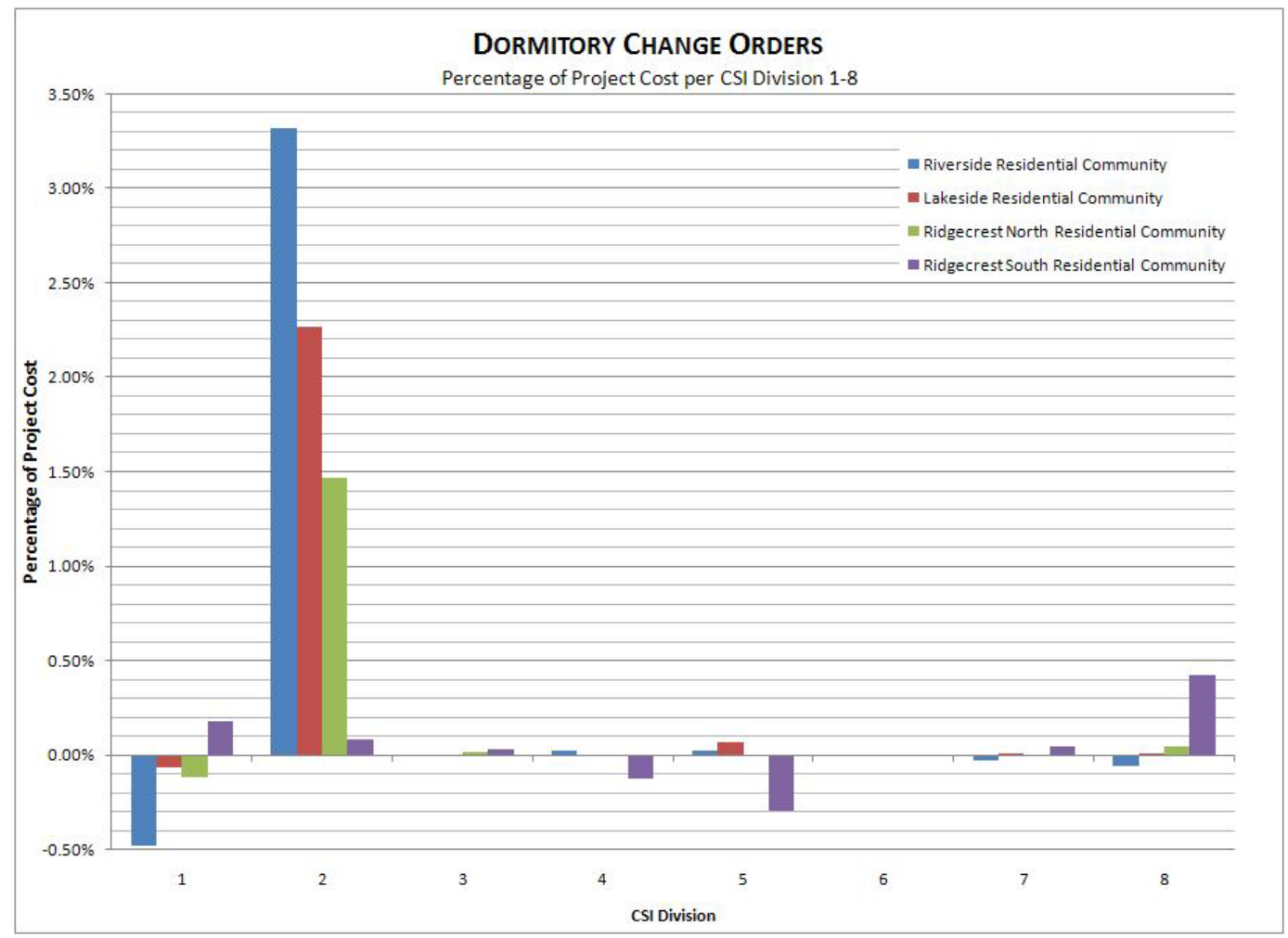

Fig. 6. Project Cost Percentage of Dormitory Change Order by CSI Divisions 1-8 


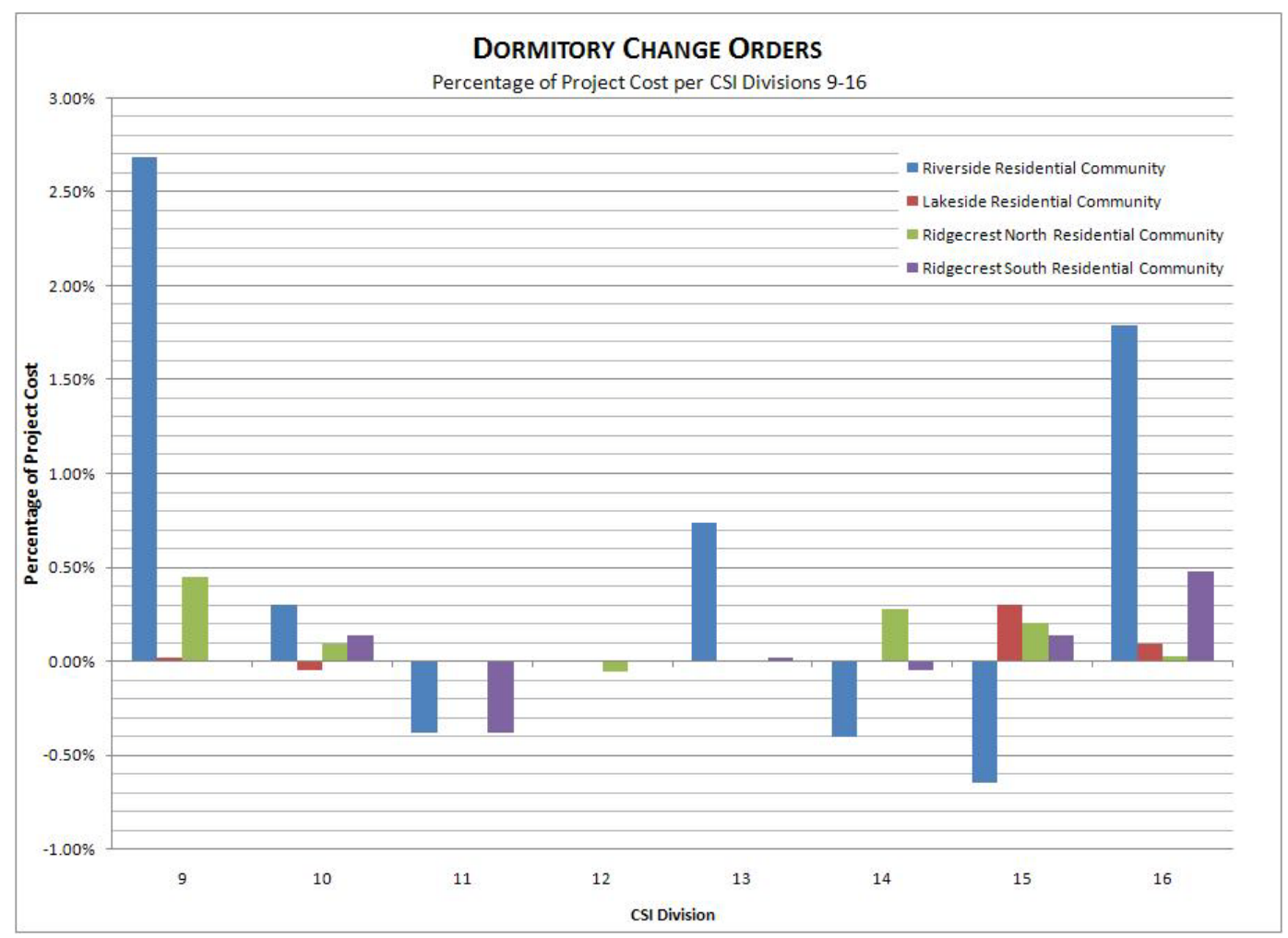

Fig. 7. Project Cost Percentage of Dormitory Change Order by CSI Divisions 9-16

The data set was also examined by combining the reason for the change and CSI analysis to study the set simultaneously. By doing so, both the reason a change order was initiated and what CSI Division the change corresponds to can be easily tracked and examined to isolate what types of changes are occurring and why they may potentially be a recurring problem. For Riverside, Lakeside, and Ridgecrest North, owner initiated changes within Division 2 accounted for either the highest or second highest costs of all categories and CSI Divisions. The cost of owner initiated Division 16 change orders within the Ridgecrest South project was the highest for that project and totaled $0.49 \%$ of the total project cost. Owner initiated changes within Division 9 and Division 16 also accounted for large change orders in the other projects; changes requested by the University to the finishes of these projects totaled 3.28\% while electrical changes increased the cost by $2.17 \%$. The combined analysis figures can be seen in Table 2 . It 
should be noted that the change orders for Ridgecrest South did not include any change order items for the integral parking deck so that a direct comparison between all four projects could be made. 
Riverside Residential Community (Project Cost - \$27,249,315)

\begin{tabular}{|c|c|c|c|c|c|c|}
\hline \multicolumn{2}{|r|}{ Reason for Change Order } & Owner Initiated & Design Error & Unforeseen & $\begin{array}{c}\text { Value } \\
\text { Engineering }\end{array}$ & \\
\hline Division 1 & General Requirements & $0.92 \%$ & - & - & $-1.40 \%$ & $-0.48 \%$ \\
\hline Division 2 & Site Construction & $2.86 \%$ & $0.43 \%$ & $0.04 \%$ & - & $3.32 \%$ \\
\hline Division 3 & Concrete & - & - & - & - & $0.00 \%$ \\
\hline Division 4 & Masonry & $0.02 \%$ & - & - & - & $0.02 \%$ \\
\hline Division 5 & Metals & - & $0.02 \%$ & - & - & $0.02 \%$ \\
\hline Division 7 & Thermal and Moisture Protection & $-0.02 \%$ & $-0.01 \%$ & - & - & $-0.03 \%$ \\
\hline Division 8 & Doors and Windows & $0.02 \%$ & - & - & $-0.08 \%$ & $-0.06 \%$ \\
\hline Division 9 & Finishes & $2.82 \%$ & - & - & $-0.14 \%$ & $2.69 \%$ \\
\hline Division 10 & Specialties & $0.32 \%$ & - & - & $-0.02 \%$ & $0.30 \%$ \\
\hline Division 11 & Equipment & $-0.38 \%$ & - & - & - & $-0.38 \%$ \\
\hline Division 12 & Furnishings & - & - & - & - & $0.00 \%$ \\
\hline Division 13 & Special Construction & $-0.02 \%$ & $0.75 \%$ & - & - & $0.74 \%$ \\
\hline Division 14 & Conveying Systems & - & - & - & $-0.40 \%$ & $-0.40 \%$ \\
\hline Division 15 & Mechanical & $0.28 \%$ & $0.09 \%$ & - & $-1.01 \%$ & $-0.65 \%$ \\
\hline Division 16 & Electrical & $1.63 \%$ & $0.25 \%$ & - & $-0.09 \%$ & $1.79 \%$ \\
\hline \multicolumn{2}{|r|}{ TOTALS } & $8.45 \%$ & $1.54 \%$ & $0.04 \%$ & $-3.14 \%$ & $6.88 \%$ \\
\hline \multicolumn{7}{|c|}{ Lakeside Residential Community (Project Cost - $\$ 26,142,240$ ) } \\
\hline \multicolumn{2}{|r|}{ Reason for Change Order } & Owner Initiated & Design Error & Unforeseen & $\begin{array}{c}\text { Value } \\
\text { Engineering }\end{array}$ & \\
\hline Division 1 & General Requirements & $0.00 \%$ & $0.28 \%$ & - & $-0.34 \%$ & $-0.06 \%$ \\
\hline Division 2 & Site Construction & $1.52 \%$ & $0.24 \%$ & $0.51 \%$ & - & $2.27 \%$ \\
\hline Division 3 & Concrete & - & - & - & - & $0.00 \%$ \\
\hline Division 4 & Masonry & - & - & - & - & $0.00 \%$ \\
\hline Division 5 & Metals & - & $0.07 \%$ & - & - & $0.07 \%$ \\
\hline Division 7 & Thermal and Moisture Protection & - & $0.00 \%$ & - & - & $0.00 \%$ \\
\hline Division 8 & Doors and Windows & - & $0.00 \%$ & - & - & $0.00 \%$ \\
\hline Division 9 & Finishes & - & $0.02 \%$ & - & - & $0.02 \%$ \\
\hline Division 10 & Specialties & $-0.04 \%$ & $-0.01 \%$ & - & - & $-0.05 \%$ \\
\hline Division 11 & Equipment & - & - & - & - & $0.00 \%$ \\
\hline Division 12 & Furnishings & $0.00 \%$ & - & - & - & $0.00 \%$ \\
\hline Division 13 & Special Construction & - & - & - & - & $0.00 \%$ \\
\hline Division 14 & Conveying Systems & - & - & - & - & $0.00 \%$ \\
\hline Division 15 & Mechanical & $0.06 \%$ & $0.25 \%$ & - & - & $0.30 \%$ \\
\hline Division 16 & Electrical & $0.04 \%$ & $0.05 \%$ & - & - & $0.09 \%$ \\
\hline \multicolumn{2}{|r|}{ TOTALS } & $1.58 \%$ & $0.90 \%$ & $0.51 \%$ & $-0.34 \%$ & $2.65 \%$ \\
\hline \multicolumn{7}{|c|}{ Ridgecrest North Residential Community (Project Cost - $\$ 33,588,000$ ) } \\
\hline \multicolumn{2}{|r|}{ Reason for Change Order } & Owner Initiated & Design Error & Unforeseen & $\begin{array}{c}\text { Value } \\
\text { Engineering }\end{array}$ & \\
\hline Division 1 & General Requirements & $-0.11 \%$ & - & - & - & $-0.11 \%$ \\
\hline Division 2 & Site Construction & $1.26 \%$ & $0.04 \%$ & $0.17 \%$ & - & $1.47 \%$ \\
\hline Division 3 & Concrete & $0.01 \%$ & - & - & - & $0.01 \%$ \\
\hline Division 4 & Masonry & - & - & - & - & $0.00 \%$ \\
\hline Division 5 & Metals & - & - & - & - & $0.00 \%$ \\
\hline Division 7 & Thermal and Moisture Protection & - & - & - & - & $0.00 \%$ \\
\hline Division 8 & Doors and Windows & $0.05 \%$ & - & - & - & $0.05 \%$ \\
\hline Division 9 & Finishes & $0.45 \%$ & $0.01 \%$ & - & - & $0.47 \%$ \\
\hline Division 10 & Specialties & - & $0.09 \%$ & - & - & $0.09 \%$ \\
\hline Division 11 & Equipment & - & - & - & - & $0.00 \%$ \\
\hline Division 12 & Furnishings & $-0.05 \%$ & - & - & - & $-0.05 \%$ \\
\hline Division 13 & Special Construction & - & - & - & - & $0.00 \%$ \\
\hline Division 14 & Conveying Systems & $0.28 \%$ & - & - & - & $0.28 \%$ \\
\hline Division 15 & Mechanical & $0.12 \%$ & $0.09 \%$ & - & - & $0.21 \%$ \\
\hline Division 16 & Electrical & $0.02 \%$ & $0.01 \%$ & - & - & $0.02 \%$ \\
\hline \multicolumn{2}{|r|}{ TOTALS } & $2.02 \%$ & $0.24 \%$ & $0.17 \%$ & $0.00 \%$ & $2.43 \%$ \\
\hline \multicolumn{7}{|c|}{ Ridgecrest South Residential Community (Project Cost - $\$ 47,200,100$ ) } \\
\hline \multicolumn{2}{|r|}{ Reason for Change Order } & Owner Initiated & Design Error & Unforeseen & $\begin{array}{c}\text { Value } \\
\text { Engineering }\end{array}$ & \\
\hline Division 1 & General Requirements & $0.16 \%$ & - & $0.02 \%$ & - & $0.18 \%$ \\
\hline Division 2 & Site Construction & - & $0.02 \%$ & $0.07 \%$ & - & $0.08 \%$ \\
\hline Division 3 & Concrete & - & $0.01 \%$ & $0.02 \%$ & - & $0.03 \%$ \\
\hline Division 4 & Masonry & $0.02 \%$ & - & - & $-0.15 \%$ & $-0.13 \%$ \\
\hline Division 5 & Metals & - & - & - & $-0.30 \%$ & $-0.30 \%$ \\
\hline Division 7 & Thermal and Moisture Protection & $0.03 \%$ & $0.07 \%$ & - & $-0.06 \%$ & $0.04 \%$ \\
\hline Division 8 & Doors and Windows & $0.43 \%$ & - & - & - & $0.43 \%$ \\
\hline Division 9 & Finishes & - & - & - & - & $0.00 \%$ \\
\hline Division 10 & Specialties & $0.14 \%$ & - & - & - & $0.14 \%$ \\
\hline Division 11 & Equipment & - & - & - & $-0.38 \%$ & $-0.38 \%$ \\
\hline Division 12 & Furnishings & - & - & - & - & $0.00 \%$ \\
\hline Division 13 & Special Construction & $0.09 \%$ & $0.01 \%$ & - & $-0.08 \%$ & $0.02 \%$ \\
\hline Division 14 & Conveying Systems & - & - & - & $-0.05 \%$ & $-0.05 \%$ \\
\hline Division 15 & Mechanical & $0.03 \%$ & $0.11 \%$ & - & - & $0.14 \%$ \\
\hline Division 16 & Electrical & $0.49 \%$ & $0.08 \%$ & - & $-0.08 \%$ & $0.48 \%$ \\
\hline & TOTALS & $1.37 \%$ & $0.29 \%$ & $0.11 \%$ & $-1.10 \%$ & $0.68 \%$ \\
\hline
\end{tabular}

Table 2. CSI Divisions Per Residential Community Costs (Note: Division 6 was omitted since there were zero changes in that Division for all projects) 
The main purpose of combining the two analyses was to determine where reductions have been made and where there is still a need for improvement in regard to design based changes. After the reduction system was implemented after the Lakeside project, areas that showed improvement included Division 2, Division 15 - Mechanical, and Division 16. All three of these Divisions showed a substantial reduction in cost associated with design-based change orders during the construction of Ridgecrest North. The downward trend continued for Division 2 for Ridgecrest South but the percentage of project cost due to design problems for Division 15 and Division 16 increased. The number of changes in Division 15 increased to $0.11 \%$ while Division 16 increased to $0.08 \%$ during the final project. The combined analysis with design related problems can be seen in Table 3 .

\begin{tabular}{|c|c|c|c|c|c|}
\hline \multicolumn{6}{|c|}{ Dormitory Design Change Order Totals - Percentage of Project Cost } \\
\hline \multicolumn{2}{|r|}{ Reason for Change Order } & \multirow{2}{*}{$\begin{array}{c}\text { Riverside Residential } \\
\text { Community }\end{array}$} & \multirow{2}{*}{$\begin{array}{c}\begin{array}{c}\text { Lakeside Residential } \\
\text { Community }\end{array} \\
0.28 \% \\
\end{array}$} & \multirow{2}{*}{$\begin{array}{c}\text { Ridegecrest North } \\
\text { Residential Community } \\
\end{array}$} & \multirow{2}{*}{$\begin{array}{c}\begin{array}{c}\text { Ridegecrest South } \\
\text { Residential Community }\end{array} \\
-\end{array}$} \\
\hline Division 1 & General Requirements & & & & \\
\hline Division 2 & Site Construction & $0.43 \%$ & $0.24 \%$ & $0.04 \%$ & $0.02 \%$ \\
\hline Division 3 & Concrete & - & - & - & $0.01 \%$ \\
\hline Division 4 & Masonry & - & - & - & - \\
\hline Division 5 & Metals & $0.02 \%$ & $0.07 \%$ & - & - \\
\hline Division 6 & Wood and Plastics & - & - & - & - \\
\hline Division 7 & Thermal and Moisture Protection & $-0.01 \%$ & $0.00 \%$ & - & $0.07 \%$ \\
\hline Division 8 & Doors and Windows & - & $0.00 \%$ & - & - \\
\hline Division 9 & Finishes & - & $0.02 \%$ & $0.01 \%$ & - \\
\hline Division 10 & Specialties & - & $-0.01 \%$ & $0.09 \%$ & - \\
\hline Division 11 & Equipment & - & - & - & - \\
\hline Division 12 & Furnishings & - & - & - & - \\
\hline Division 13 & Special Construction & $0.75 \%$ & - & - & $0.01 \%$ \\
\hline Division 14 & Conveying Systems & - & - & - & - \\
\hline Division 15 & Mechanical & $0.09 \%$ & $0.25 \%$ & $0.09 \%$ & $0.11 \%$ \\
\hline Division 16 & Electrical & $0.25 \%$ & $0.05 \%$ & $0.01 \%$ & $0.08 \%$ \\
\hline & TOTALS & $1.54 \%$ & $0.90 \%$ & $0.24 \%$ & $0.29 \%$ \\
\hline
\end{tabular}

Table 3. Dormitory Design Change Order Totals Percentage of Project Costs 
The checklists developed in the previous study were used by both the in-house design reviewers at the University and the author during the design review process. The previous global change order study also examined research/classroom buildings and parking decks, and checklists were also developed for these types of facilities. As an example, during the design phase of the Science and Engineering Complex (SEC), the author had the opportunity to use the checklist and change orders from a similar project (Shelby Hall, a \$46 million research/classroom facility, had 187 change orders that contributed $10.6 \%$ to the final project cost) to look for potential changes. With aid from the Assistant Vice President of Facilities Design and Construction at the University, the review process yielded several potential change items that had resulted in change orders during the Shelby Hall construction project. These items consisted of mislabeled beams, no power to automatic door openers, and discrepancies between the architectural reflected ceiling plans and the electrical lighting drawings. None of these items, however, were on the old checklist and were actually found by looking at the change orders from the Shelby Hall project and then examining the SEC plans for that specific problem. The plans for the Ridgecrest South project were also reviewed by the author with no assistance. No potential change order items were found during this review, but this could be attributed to the author's limited experience and knowledge of design document reviews. 


\section{CHAPTER 4}

\section{RECOMMENDATIONS}

An effective change order reduction program to be used by the University should consist of two core sections: change prevention and change management. The fundamental purpose of the program would be to avoid unnecessary changes to the project scope and to catch obvious mistakes with the project plans and specifications that would cause problems with construction later in the life-cycle of the project while incorporating lessons learned for continuous improvement. The change management system would heavily depend on both sections of the program; to be a successful program, each section must work to better improve the other. A stronger and more thorough lessons learned system could then be developed from the knowledge gained from the management aspect in areas such as the occurrence of major changes in the project schedule and common design problems that are seen on subsequent projects.

Change order prevention is a pro-active measure that the University should employ on a consistent basis, regardless of project type, size, and cost. This preventive system would seek to anticipate major, costly changes before they could hinder the project budget and schedule. These preventative tasks should be carried out well before the project is bid, typically occurring in the planning and design phases of the project lifecycle. During the planning phase of the project, the University planners should and typically do develop a well-defined project scope that would meet all the business criteria that is necessary for the project to be profitable for the University while also meeting the needs of the students, faculty, and visitors as well as the maintenance and 
facility managers who would be responsible with the upkeep of the building. Any major changes to the scope should be made at this point in the project timeline and the modification should be well-documented and broadcasted to all departments of the University affected by the change. The changes that are made to the scope during planning may cause some minor setbacks but would not have the substantial impact a change order that dramatically alters the project's scope would have during the detailed design phase or construction phase of the project.

Design document reviews are also an effective way to prevent costly change orders. As building systems become more and more complex, mistakes by the design professionals are an inevitable and unfortunate occurrence. There are no error-free plans and specifications; both of these documents need to be thoroughly checked and rechecked during the entire design phase of the project. Once the project scope has been defined and the main aspects of the facility have been accepted, a basic design with sketches and schematics of the facility that incorporates the fundamental details of the scope should be produced and reviewed by any organization within the University that have responsibilities in the planning, design, construction, and use of the facility. During the detailed design review, the members charged with reviewing the drawings should routinely use the detailed checklist developed in this study, or a similar checklist, to scan the documents and check for deficiencies within the plans and specifications. Another recommendation would be to hire outside consultants to review the plans and specifications during the detailed design phase of large campus projects. These individuals would be able to catch mistakes that the principal designer and the reviewers may have missed. The revised checklist to be used during the review of the dormitory design documents can be seen in Appendix 2. 
Change order management is the process of tracking, monitoring, and analyzing change orders during the construction phase of the project. The main goals of change order management are to better understand where the changes are coming from, why they were needed, and how much impact these changes will have on the overall project schedule and budget. To effectively meet these objectives, the change orders and their impact must be assessed by some measurable means that offer a simple method of data entry and the ability to accurately analyze this data so that the information can easily observed and the knowledge drawn from the analysis can be used in a constructive fashion. This can easily be accomplished by continuing to utilize the metrics that were used in this study.

One of the best ways for the University to track the information from formal changes to the contract is the change order form and the change order justification form. The official change order form has important data entries such as the change order number, the date the change order was approved, and a breakdown of the change order items. The change order justification form used by the University has a separate sheet for each of the change order items and lists details such as who initiated the change and why it was requested. To properly track change orders, the justification form should be restructured to include the seven reasons for the change order and to what CSI Division the change belongs. This will allow for a straightforward approach to tracking and monitoring changes during and after construction and will provide the University with a comprehensive breakdown of change orders.

A change order form and justification form that lists all of the individual change items and the corresponding Change Order Request (COR) number is essential to properly track vital information that is necessary to manage costly changes to the campus construction projects. If no COR was created or processed, then the Request for Proposal (RFP) or the Architect's 
Supplemental Instructions (ASI) and Requests for Information (RFI) that were issued by the architect and contractor, respectively, can be used to trace the original cause of the change order item. The information on these documents will indicate what the problem is and what needs to be done to remedy the situation. These details, especially the details for changes that are a recurring problem, can then be added to the design review checklist to strengthen its ability to detect potential problems or obstacles in future dormitory construction projects. All of the aforementioned documents should be entered into a project log book when they are received and then should be compiled into one folder so that change orders can be properly organized and readily accessible. The project manager should be the person solely responsible for making sure all of the documentation is accounted for and in order.

To further enhance their change management system, the University should also consider creating a change order oversight committee. This group should consist of the director of construction and all of the in-house project managers, and would be responsible for design reviews, reviewing change orders during and after a project, managing the change order database, and to identify lessons learned from the change managements system. One of the first actions of the oversight committee should be to review the acceptable range for the percentage of change order cost based on the total project cost. This percentage can then be subdivided to develop a percentage range for each reason for change and CSI Division, and doing so will allow the University to monitor and track the performance of projects based on changes. For example, if error/omission changes in Division 15 - Mechanical resulted in a change percentage over the University standard, then the University could examine these changes more closely and determine if any action should be taken against the mechanical/plumbing consulting firm. 


\section{CHAPTER 5}

\section{DISCUSSION}

One of the main concerns the University had regarding change orders was designer error. Several large projects on campus have been built in the past five years and some of these facilities had numerous and expensive design-based change orders that greatly impacted the construction budget and schedule. Since the dormitories basically feature the same design styles, there was some speculation that the members of the design team had some bearing on the type and frequency of change orders during the construction of the dormitories due to inadequate design documents. Examples of the kind of influence that designers can have on multiple projects include repeated design flaws by the same design team from one building to the next and the impact of changing design firms between projects. By retaining the same design members throughout the construction of several buildings, the designers can learn from the mistakes they made in the first project; if their services are retained for another like project, the ability to quickly generate a set of plans and specifications for the next project will be very valuable and the likelihood of repeated mistakes is lessened. They will also be able to develop a better understanding of the requirements the owner may have for the building and what the owner expects from the design. The continuity and professional relationships a design firm will create with the other designers and the construction managers/owners will expedite the design process and would lead to fewer preventable errors and omissions on future projects. 
The number of change orders originating from designer problems can have a considerable impact on the project. A study by Hanna that quantitatively defined the impacts change orders had on mechanical and electrical contractors illustrated that there is a direct correlation between the numbers of change orders resulting from inadequate design documents and the increased impact these changes will have on the project (Hanna 2002). The findings of that study showed that unimpacted projects had a lower percentage of changes resulting from design problems. Of the projects studied, impacted projects averaged approximately $50 \%$ of their changes resulting from design problems; however, unimpacted projects averaged $38 \%$ of the total change orders resulting from designer error (Hanna 2002). Three of the four projects (Riverside, Ridgecrest North, and Ridgecrest South) had design error percentages below 50\% while the percentage of changes resulting from design problems for Lakeside, the second dormitory in the series, was approximately $65 \%$ of the total change order occurrences. However, the cost of design problem changes for Lakeside was $0.9 \%$ of the total project cost. Riverside, which had approximately $1.5 \%$ of the project cost resulting from designer error, had only $31 \%$ of change items resulting from problems with the designs. Further research should be conducted that would analyze the total direct and indirect impact to the project budget and schedule that design related changes has had on campus construction.

To analyze how the switch in the design professionals may have influenced the number of change items and the cost, the change order items were once again separated by reason for the change and by CSI Division. For example, Division 2 - Site Construction changes were examined for any changes related to the civil engineer while Division 15-Mechanical changes were studied for items that can be attributed to the mechanical/plumbing design consultants. Only change orders resulting from design error were analyzed to ensure that data being used was 
solely the fault of these designers and not distorted by scope changes or other possible reasons.

The design team members for each project can be seen in Table 4.

\begin{tabular}{|c|c|c|c|c|c|c|}
\hline & Architect & Structural Engineer & $\begin{array}{c}\text { Mechanical/Plumbing } \\
\text { Engineer }\end{array}$ & Electrical Engineer & Civil Engineer & Contractor \\
\cline { 2 - 7 } $\begin{array}{c}\text { Riverside } \\
\text { Residential } \\
\text { Community }\end{array}$ & A-1 & SE-1 & M/PE-1 & EE-1 & C-1 \\
\hline $\begin{array}{c}\text { Lakeside } \\
\text { Residential } \\
\text { Community }\end{array}$ & A-1 & SE-1 & M/PE-1 & EE-1 & CE-1 & C-1 \\
\hline $\begin{array}{c}\text { Ridgecrest } \\
\text { North } \\
\text { Residential } \\
\text { Community }\end{array}$ & A-1 & SE-1 & M/PE-2 & EE-1 & CE-2 & C-1 \\
\hline $\begin{array}{c}\text { Ridgecrest } \\
\text { South } \\
\begin{array}{c}\text { Residential } \\
\text { Community }\end{array}\end{array}$ & A-1 & SE-2 & M/PE-2 & EE-2 & CE-2 & C-2 \\
\hline
\end{tabular}

Table 4. Construction Team List

From the completion of Riverside and Lakeside to the planning and design of Ridgecrest North, the majority of the design team members remained the same while others were replaced by another firm. The University retained the principal architect, structural engineer, and electrical engineer that designed Riverside and Lakeside dormitories to provide the same services for the Ridgecrest North project; the mechanical/plumbing engineering and civil engineering firms, however, changed from the previous two construction projects. The structural and electrical engineers employed in the design of Ridgecrest North were not used as consulting engineers for the Ridgecrest South project. From this analysis, it was shown that retaining design consultants from one project to the next resulted in fewer significant errors and reduced change order costs. The electrical engineers, for example, that worked on the first three dormitory projects made less costly design errors from the Riverside project through the construction of Ridgecrest North. Retaining the services of the consultants resulted in two 
scenarios: the design team reduced the cost of design based changes or the cost increased during the next project. There were two instances when retaining the same design firm did not result in fewer change orders; both instances involved the mechanical engineering firms. From Riverside to Lakeside, the mechanical engineers increased the percentage cost by $0.16 \%$ while the cost was increased by $0.02 \%$ from Ridgecrest North to Ridgecrest South. The civil engineers and the electrical engineers all showed a reduction in the cost of design changes when allowed to work on sequential projects. Therefore, for the majority of cases, retaining the same engineering firms to provide consultation services on sequential building projects suggests a reduction in the percentage of cost for design based changes, but this should be studied further to determine the entire impact of retaining the same design team during a construction program. It should be noted that the increased cost of design based changes within Division 16 during the Ridgecrest South project was more attributable to several complex program changes during construction rather than the fault and negligence of the electrical engineers. 


\section{CHAPTER 6}

\section{CONCLUSIONS}

Change orders during large, complex projects are an unavoidable reality in the construction industry. Some of these changes can be beneficial, such as adding features and amenities that will enhance the facility after certain risk points have been passed in the project time-line or if more monies becomes available, but even these changes will prove detrimental to the project schedule and budget while sometimes creating strained relationships between all of the major members associated with the project. Changes during the construction of dormitory projects on the University campus averaged $3.16 \%$ of the total cost per project, and the majority of the change orders processed during the construction of these residential communities were initiated by the University while design-based changes averaged $0.74 \%$ of the total cost per project. Owner requested changes and scope changes averaged 3.16\% of the combined costs of the four projects studied, with $1.29 \%$ of the total cost resulting from owner initiated changes within Division 2 alone.

Overall, the change orders during the dormitory construction program showed a decrease in the total number of changes and percentage of project cost from Riverside to the completion of Ridgecrest South. The number of occurrences and the percentage cost of design based changes also decreased during the last two projects. The reduction in these changes cannot be directly attributed to the checklist developed in the previous study since none of the items listed on the checklist were identified by the in-house reviewers in their design review comments due to the 
generality of the checklist. However, the checklist was revised to provide greater detail to detect potential design errors and will also give the University a means to check that the design is inline with the scope of the project.

One of the five steps identified by CII for proper project change management is to continuously improve from lessons learned. The steps listed in the CII Project Change Management publication include:

1. Performing root cause evaluations

2. Preparing lessons learned

3. Updating databases in regard to cost, scope, schedule, and timing

4. Comparing results to initial objectives

5. Incorporating lessons learned

6. Adding significant items to project checklist

7. Adding significant measurements to standard reporting system

8. Updating procedures (CII 1994).

The University should continue to use the spreadsheet and the reason for the change and CSI analysis metrics detailed in this study to perform the root cause evaluations. The change data and lessons learned can then be used to update the change databases. More study, however, should be done to include both the direct and indirect cost impacts as well as the effects changes had on the project scope and schedule so that a more comprehensive analysis can be performed. For example, one of the lessons learned during the construction of Ridgecrest North and South is that the checklist used was too general in nature and needs to be more detailed. While these steps are just the beginning of a change order lessons learned system, they provide the basis for continuous improvement of the project change management system at the University. 


\section{REFERENCES}

Cho, C. S., and Gibson, G. E. (2001). "Building project scope definition using project definition rating index.” J. Arch. Eng., 7(4), 115-125

Clough, R. H., Sears, G. A., and Sears, S. K. (2005). Construction contracting: a practical guide to company management, $7^{\text {th }}$ Ed., Wiley, Hoboken, N.J.

Construction Industry Institute (CII). (1990). "The impact of changes on construction cost and schedule." Publication 6-10, Univ. of Texas at Austin, Austin, Tex.

Construction Industry Institute (CII). (1994). "Project change management." Special Publication 43-1, Univ. of Texas at Austin, Austin, Tex.

Gould, F. E., and Joyce, N. E. (2003). Construction project management, $2^{\text {nd }}$ Ed., Prentice-Hall, Upper Saddle River, N.J.

Günhan, S ., A rditi, D ., a nd D oyle, J . ( 2007). “ Avoiding c hange o rders i n publ ic s chool construction.” J. Prof. Iss. In Eng. Ed. And Prac., ASCE, 133(1), 67-73

Hanna, A. S., R usell, J. S., Nordheim, E. V., and Bruggink, M. J. (1999). "Impact of Change Orders on Labor E fficiency for E lectrical C onstruction." J. Constr. Eng. Manage., $125(4), 224-232$

Hester, W . T ., K uprenas, J . A ., a nd C hang, T . C. (1991). "Construction c hanges a nd c hange orders: their magnitude and impact." Report to Construction Industry Institute, Univ. of Texas at Austin, Austin, Tex.

Ibbs, C . W ., a nd A llen, W .E . ( 1995). "Quantitative i mpacts of pr oject c hange.” Source Document, 108. Construction Industry Institute, Univ. of Texas at Austin, Austin, Tex.

O’Brien, J. J. (1998). Construction change orders: impact, avoidance, documentation. McGrawHill, New York. 


\section{APPENDIX}

\section{Appendix A: CSI Divisions and Sub-divisions}

\begin{tabular}{|c|c|c|c|}
\hline & CSI Divisions & Number of CO Items & Cost \\
\hline Division 1 & General Requirements & & \\
\hline 1.1 & General Requirements, Administrative, and Accounting & & \\
\hline Division 2 & Site Construction & & \\
\hline 2.1 & Basic Site Materials and Methods & & \\
\hline 2.2 & Site Preparation & & \\
\hline 2.3 & Earthwork & & \\
\hline 2.4 & Foundation and Load-Bearing Elements & & \\
\hline 2.5 & Utility Services & & \\
\hline 2.6 & Drainage and Containment & & \\
\hline 2.7 & Bases, Ballasts, Pavements, and Appurtenances & & \\
\hline 2.8 & Site Improvements and Amenities & & \\
\hline 2.9 & Planting & & \\
\hline Division 3 & Concrete & & \\
\hline 3.1 & Basic Concrete Materials and Methods & & \\
\hline 3.2 & Concrete Forms and Accessories & & \\
\hline 3.3 & Concrete Reinforcement & & \\
\hline 3.4 & Cast-In-Place Concrete & & \\
\hline 3.5 & Precast Concrete & & \\
\hline 3.6 & Grouts & & \\
\hline 3.7 & Mass Concrete & & \\
\hline Division 4 & Masonry & & \\
\hline 4.1 & Basic Masonry Materials and Methods & & \\
\hline 4.2 & Masonry Units & & \\
\hline 4.3 & Stone & & \\
\hline 4.4 & Masonry Assemblies & & \\
\hline Division 5 & Metals & & \\
\hline 5.1 & Basic Metal Materials and Methods & & \\
\hline 5.2 & Structural Metal Framing & & \\
\hline 5.3 & Metal Joists & & \\
\hline 5.4 & Metal Deck & & \\
\hline 5.5 & Cold-Formed Metal Framing & & \\
\hline 5.6 & Metal Fabrications & & \\
\hline 5.7 & Ornamental Metal & & \\
\hline 5.8 & Expansion Control & & \\
\hline
\end{tabular}


Division 6 Wood and Plastics

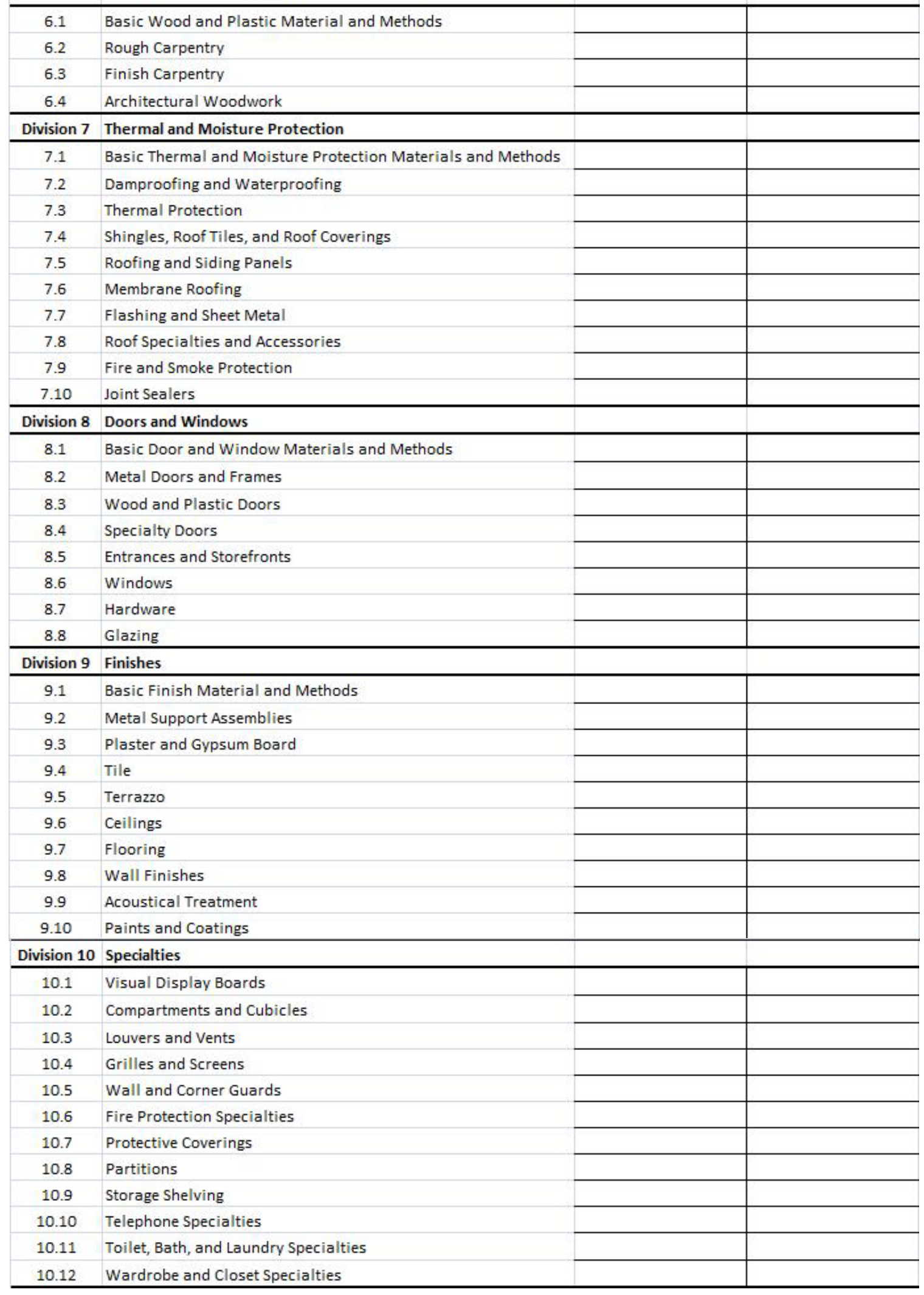


Division 11 Equipment

\begin{tabular}{|c|c|c|c|}
\hline 11.1 & Maintenance Equipment & & \\
\hline 11.2 & Vending Equipment & & \\
\hline 11.3 & Audio-Visual Equipment & & \\
\hline 11.4 & Parking Control Equipment & & \\
\hline 11.5 & Food Service Equipment & & \\
\hline 11.6 & Residential Equipment & & \\
\hline 11.7 & Unit Kitchens & & \\
\hline 11.8 & Laboratory Equipment & & \\
\hline 11.9 & Office Equipment & & \\
\hline Division 12 & Furnishings & & \\
\hline 12.1 & Fabrics & & \\
\hline 12.2 & Art & & \\
\hline 12.3 & Manufactured Casework & & \\
\hline 12.4 & Furnishings and Accessories & & \\
\hline 12.5 & Furniture & & \\
\hline 12.6 & Multiple Seating & & \\
\hline 12.7 & Systems Furniture & & \\
\hline Division 13 & Special Construction & & \\
\hline 13.1 & Lightning Protection & & \\
\hline 13.2 & Swimming Pools & & \\
\hline 13.3 & Security Access and Surveillance & & \\
\hline 13.4 & Building Automation and Control & & \\
\hline 13.5 & Detection and Alarm & & \\
\hline 13.6 & Fire Suppression & & \\
\hline Division 14 & Conveying Systems & & \\
\hline 14.1 & Elevators & & \\
\hline Division 15 & Mechanical & & \\
\hline 15.1 & Basic Mechanical Materials and Methods & & \\
\hline 15.2 & Building Service Piping & & \\
\hline 15.3 & Process Piping & & \\
\hline 15.4 & Fire Protection Piping & & \\
\hline 15.5 & Plumbing Fixtures and Equipment & & \\
\hline 15.6 & Heat-Generations Equipment & & \\
\hline 15.7 & Refrigeration Equipment & & \\
\hline 15.8 & Heating, Ventilating, and Air Conditioning Equipment & & \\
\hline 15.9 & Air Distribution & & \\
\hline 15.10 & HVAC Instrumentation and Controls & & \\
\hline 15.11 & Testing, Adjusting, and Balancing & & \\
\hline Division 16 & Electrical & & \\
\hline 16.1 & Basic Electrical Materials and Methods & & \\
\hline 16.2 & Wiring Methods & & \\
\hline 16.3 & Electrical Power & & \\
\hline 16.4 & Transmission and Distribution & & \\
\hline 16.5 & Low-Voltage Distribution & & \\
\hline 16.6 & Lighting & & \\
\hline 16.7 & Communications & & \\
\hline \multirow[t]{2}{*}{16.8} & Sound and Video & & \\
\hline & TOTAL $=$ & & \\
\hline
\end{tabular}




\section{Appendix B: Dormitory Design Review Checklist}

\section{Dormitory Design Review Checklist}

\section{Division 2: Site Construction}

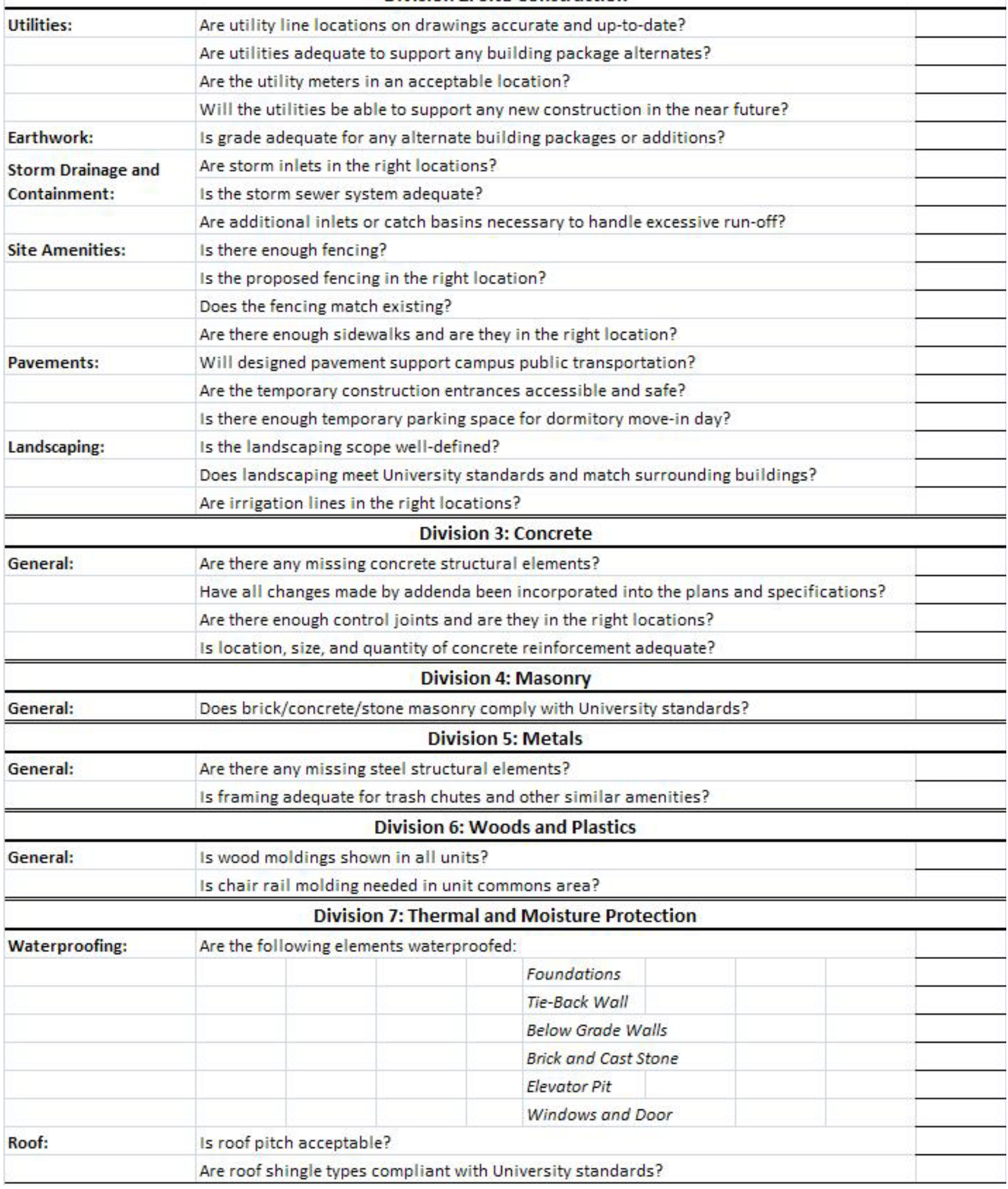




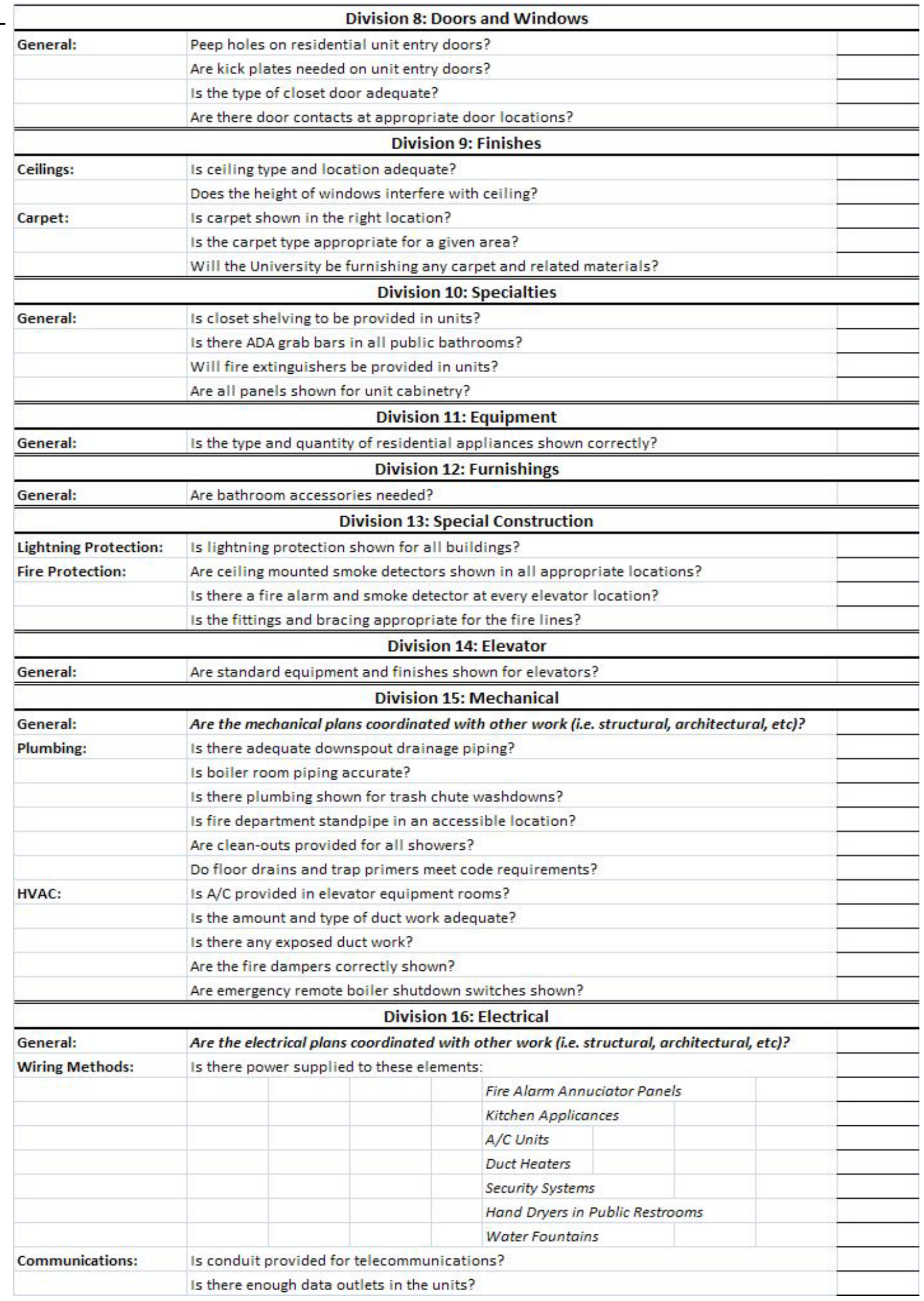

